\title{
Antibiotic, cytotoxic and enzyme inhibitory activity of crude extracts from Brazilian marine invertebrates
}

\author{
Mirna H. R. Seleghim ${ }^{1,2}$, Simone P. Lira ${ }^{1}$, Miriam H. Kossuga ${ }^{1}$, Tatiana Batista ${ }^{1}$, Roberto G. \\ S. Berlinck ${ }^{1 *}$, Eduardo Hajdu ${ }^{3}$, Guilherme Muricy ${ }^{3}$, Rosana M. da Rocha ${ }^{4}$, Gislene G. F. do \\ Nascimento $^{5}$, Marcio Silva ${ }^{6}$, Eli F. Pimenta ${ }^{6}$, Otávio H. Thiemann ${ }^{6}$, Glaucius Oliva ${ }^{6}$, Bruno $^{2}$ \\ C. Cavalcanti ${ }^{7}$, Claudia Pessoa ${ }^{7}$, Manoel O. de Moraes ${ }^{7}$, Fabio C. S. Galetti ${ }^{8}$, Celio L. Silva ${ }^{8}$, \\ Ana O. de Souza ${ }^{9}$, Solange Peixinho ${ }^{10}$
}

${ }^{1}$ Instituto de Química de São Carlos, Universidade de São Paulo, CP 780, 13560-970, São Carlos, SP, Brazil, ${ }^{2}$ Departamento de Ecologia e Biologia Evolutiva, Universidade Federal de São Carlos, 13565-905, São Carlos, SP, Brazil,

${ }^{3}$ Museu Nacional, Universidade Federal do Rio de Janeiro, Quinta da Boa Vista, s/n, 20940-040, Rio de Janeiro, RJ, Brazil,

${ }^{4}$ Departamento de Zoologia, Setor de Ciências Biológicas, Universidade Federal do Paraná, CP 19020, 81531-990, Curitiba, PR, Brazil,

${ }^{5}$ Faculdade de Ciências da Saúde, Universidade Metodista de Piracicaba, 13400-911, Piracaba, SP, Brazil,

${ }^{6}$ Instituto de Física de São Carlos, Universidade de São Paulo, 13566-590, São Carlos, SP, Brazil,

${ }^{7}$ Departamento de Fisiologia e Farmacologia, Laboratório de Oncologia Experimental, Universidade Federal do Ceará, 60431-970, Fortaleza, CE, Brazil,

${ }^{8}$ Departamento de Bioquímica e Imunologia, Faculdade de Medicina de Ribeirão Preto, Universidade de São Paulo, 14049-900, Ribeirão Preto, SP, Brazil,

${ }^{9}$ Laboratório de Bioquímica e Biofísica, Instituto Butantan, 05503-900, São Paulo, SP, Brazil,

${ }^{10}$ Departamento de Biologia, Universidade Federal da Bahia, 40220-141, Salvador, BA, Brazil

\begin{abstract}
RESUMO: “Atividade antibiótica, citotóxica e de inibição enzimática de extratos brutos de invertebrados marinhos do Brasil”. No presente estudo apresentamos resultados da triagem biológica realizada com 349 extratos obtidos de esponjas marinhas, ascídias, briozoários e octocorais do Brasil, em testes contra 16 linhagens de bactérias comuns e resistentes à antibióticos, uma levedura (Candida albicans), Mycobacterium tuberculosis H37Rv, três linhagens de células tumorais MCF-7 (mama), B16 (melanoma murínico) e HCT8 (cólon), e de inibição da enzima adenina fosforribosil transferase de Leishmania tarentolae (L-APRT). Menos de 15\% dos extratos de esponja marinhas apresentaram atividade antibacteriana, contra linhagens resistentes ou não a antibióticos. Quase $40 \%$ dos extratos de esponjas marinhas apresentaram atividade antimicobacteriana contra Mycobacterium tuberculosis H37Rv. Foi observada citotoxicidade para $18 \%$ dos extratos de esponjas marinhas. Finalmente, menos de $3 \%$ dos extratos de esponjas apresentaram atividade inibitória da enzima L-APRT. Menos de 10\% dos extratos de ascídias apresentaram atividade antibacteriana. Mais de 25\% dos extratos de ascídias apresentaram atividade contra $M$. tuberculosis e as três linhagens de células tumorais. Somente dois extratos obtidos da ascídia Polysyncraton sp. coletada em duas diferentes épocas (1995 e 1997) apresentaram atividade contra L-APRT. Menos de $2 \%$ dos extratos de briozoários e octocorais apresentaram atividade antibacteriana, mas uma alta percentagem de extratos destes animais apresentaram atividades citotóxica (11\% e $30 \%$, respectivamente) e antimicobacteriana $(60 \%)$. O extrato de somente uma espécie de briozoário, Bugula sp., apresentou atividade inibitória da enzima LAPRT. A análise taxonômica de algumas espécies de invertebrados que forneceram alguns dos extratos mais ativos, indicou a ocorrência de atividade biológica em espécies pertencentes a grupos taxonômicos que já foram anteriormente investigados do ponto de vista químico. Estes incluem esponjas marinhas pertencentes aos gêneros Aaptos, Aplysina, Callyspongia, Haliclona, Niphates, Cliona, Darwinella, Dysidea, Ircinia, Monanchora e Mycale, ascídias dos gêneros Didemnum, Aplidium, Botrylloides, Clavelina, Polysyncraton e Symplegma, o briozoário Bugula sp. e octocorais dos gêneros Carijoa e Lophogorgia. A subseqüente investigação química de alguns dos extratos ativos levou ao isolamento de vários metabólitos secundários biologicamente ativos. Os resultados obtidos estão de acordo com resultados obtidos em programas de triagem de atividade biológica de extratos brutos de invertebrados marinhos anteriormente reportados, que apresentaram altas percentagens de extratos bioativos oriundos de Porifera, Ascidiacea, Cnidária e Bryozoa.
\end{abstract}


Unitermos: Triagem biológica, esponjas marinhas, ascídias, briozoários, octocorais, antibacteriano, citotóxico, antimicobacteriano, inibidor enzimático.

\begin{abstract}
Herein we present the results of a screening with 349 crude extracts of Brazilian marine sponges, ascidians, bryozoans and octocorals, against 16 strains of susceptible and antibiotic-resistant bacteria, one yeast (Candida albicans), Mycobacterium tuberculosis H37Rv, three cancer cell lines MCF-7 (breast), B16 (murine melanoma ) and HCT8 (colon), and Leishmania tarentolae adenine phosphoribosyl transferase (L-APRT) enzyme. Less than $15 \%$ of marine sponge crude extracts displayed antibacterial activity, both against susceptible and antibiotic-resistant bacteria. Up to $40 \%$ of marine sponge crude extracts displayed antimycobacterial activity against $M$. tuberculosis H37Rv. Cytotoxicity was observed for $18 \%$ of marine sponge crude extracts. Finally, less than $3 \%$ of sponge extracts inhibited L-APRT. Less than $10 \%$ of ascidian crude extracts displayed antibacterial activity. More than $25 \%$ of ascidian crude extracts were active against $M$. tuberculosis and the three cancer cell lines. Only two crude extracts from the ascidian Polysyncraton sp. collected in different seasons (1995 and 1997) displayed activity against L-APRT. Less than $2 \%$ of bryozoan and octocoral crude extracts presented antibacterial activity, but a high percentage of crude extracts from bryozoan and octororal displayed cytotoxic ( $11 \%$ and $30 \%$, respectively) and antimycobacterial (60\%) activities. The extract of only one species of bryozoan, Bugula sp., presented inhibitory activity against L-APRT. Overall, the crude extracts of marine invertebrates herein investigated presented a high level of cytotoxic and antimycobacterial activities, a lower level of antibacterial activity and only a small number of crude extracts inhibited L-APRT. Taxonomic analysis of some of the more potently active crude extracts showed the occurrence of biological activity in taxa that have been previously chemically investigated. These include marine sponges belonging to genera Aaptos, Aplysina, Callyspongia, Haliclona, Niphates, Cliona, Darwinella, Dysidea, Ircinia, Monanchora and Mycale, ascidians of the genera Didemnum, Aplidium, Botrylloides, Clavelina, Polysyncraton and Symplegma, the bryozoan Bugula sp. and octocorals of the genera Carijoa and Lophogorgia. The subsequent chemical investigation of some of the active extracts led to the isolation of several new biologically active secondary metabolites. Our results are in agreement with previous screening programs carried out abroad, that showed a high percentage of bioactive extracts from Porifera, Ascidiacea, Cnidaria and Bryozoa.
\end{abstract}

Keywords: Biological screening, marine sponges, ascidians, bryozoans, octocorals, antibacterial, cytotoxic, antimycobacterial, enzymatic inhibitor.

\section{INTRODUCTION}

Soft-bodied sessile marine invertebrates constitute the largest biomass of the marine macrofauna in many marine habitats. The storage of biologically active secondary metabolites by marine invertebrates is frequently related to their ecological success, in spite of their exposition to predation, infestation by microbial pathogens, overgrowth, fouling and competition for space and nutrients (reviewed in Amsler et al., 2001; Blunt et al., 2007; Faulkner et al., 2004; Lindquist, 2002; Paul, 1992; Pawlik, 1993; Stachowicz, 2001). Marine sponges, ascidians, soft-bodied cnidaria and bryozoans are representative groups of marine invertebrates which are chemically defended against predators (for selected examples, see Aceret et al., 2001; Becerro et al., 1998; Burns et al., 2003; Chanas et al., 1996; Epifanio et al., 1999a; Epifanio et al., 1999b; Kubanek et al., 2002; Lindel et al., 2000; Lindquist, 1996; Marin et al., 1998; McClintock and Baker, 1997; O’Neal and Pawlik, 2002; Pawlik et al., 1995; Pisut and Pawlik, 2002; Stachowicz and Lindquist, 1997; Van Alstyne et al., 1994; Vervoort et al., 1998; Waddell and Pawlik, 2000), fouling (Becerro et al., 1997; Bhosale et al., 2002; Hattori et al., 2001;
Henrikson and Pawlik, 1995; Kelly et al., 2003; Wahl et al., 1994), larval settlement (reviewed in Davis et al., 1989; Fusetani, 1997; Martín and Uriz, 1993; Pawlik, 1992) and solar UV radiation (Bandaranayake et al., 1996; Dionisio-Sese et al., 1997; Dunlap et al., 1986; Stachowicz and Lindquist, 1997). The chemical defenses of sessile marine invertebrates may not only possess a specific ecological or physiological role, but may also exert a multitude of biological activities, as it has been demonstrated for the Mediterranean sponge Crambe crambe (Becerro et al., 1994; Uriz et al., 1995; Becerro et al., 1995; Turon et al., 1996; Uriz et al., 1996; Becerro et al., 1997; Turon et al., 1998; Galera et al., 2000), which is a source of potent antibiotic and cytotoxic structurally complex polycyclic guanidine alkaloids (Berlinck et al., 1990; 1992; 1993; Jares-Erijman et al., 1991; 1993a; 1993b). Other examples of secondary metabolites from marine sponges which display a broad range of biological activities are halitoxins and amphitoxins, isolated from the Haplosclerid sponges Amphimedon viridis, A. compressa, Reniera sarai, Callyspongia ridleyi and $C$. fibrosa (reviewed in Berlinck et al., 2004).

Since they accumulate chemical defenses, marine invertebrates have been screened in a variety of 
pharmacological bioassays. Biological activities which have been frequently observed in marine invertebrate crude extracts include antibiosis against both human microbial pathogens and marine microorganisms (Slattery et al., 1997; Encarnación et al., 2000; Kuniyoshi and Higa, 2001) and cytotoxicity (reviewed in Garson, 1994; Cragg and Newman, 1999; Munro et al., 1999; Rinehart, 2000; Schmitz, 1994; Mayer, 1999; Mayer and Lehmann, 2001; Mayer and Hamann, 2002; Mayer and Gustafson, 2003 and 2006; Mayer et al., 2007). The fact that many marine invertebrate secondary metabolites have presented both antibiotic and cytotoxic activities is not only a consequence of their intrinsic activity, but also because research towards the search for new drugs has focused mainly on these bioassays (Newman et al., 2003). Several other biological activities have been reported for secondary metabolites isolated from marine invertebrates, such as antifungal, antihistaminic, antihypertensive, antiviral, antiparasitic, antioxidative, herbicidal, immunosupressive, among others (Mayer and Hamann, 2002; Munro and Blunt, 2007; Takamatsu et al., 2003). Therefore, secondary metabolites from marine invertebrates have been targeted as new lead compounds in pharmaceutical, agrochemical, food and nutraceuticals industry research programs (De Vries and Beart, 1995; Jack, 1998; Kerr and Kerr, 1999; Faulkner, 2000a,b; Blunden, 2001; Cragg and Newman, 2001; Proksch et al., 2002; Quinn et al., 2002; Haefner, 2003; Peng et al., 2003).

The pharmacological evaluation of crude extracts obtained from a limited number of Brazilian marine invertebrates illustrated potential cytotoxic (Rangel et al., 2001; Monks et al., 2002; Jimenez et al., 2003; Prado et al., 2004), antimicrobial (Muricy et al., 1993; Monks et al., 2002), hemolytic and neurotoxic (Rangel et al., 2001; Dresch et al., 2005) activities. The present investigation reports the pharmacological evaluation of more than 300 crude extracts obtained from marine sponges, ascidians, bryozoans and octocorals, in bioassays of antimycobacterial activity against Mycobacterium tuberculosis H37Rv, antibiotic activity against sixteen susceptible and resistant strains of bacteria and Candida albicans, inhibition of the enzyme adenine phosphoribosyl transferase of Leishmania tarentolae (L-APRT), as well as cytotoxic activity against colon (HCT8), melanoma (B16) and breast (MCF-7) cancer cell lines. Additionally, we summarize the results obtained from the chemical investigation of some active crude extracts which yielded bioactive secondary metabolites.

\section{MATERIAL AND METHODS}

\section{Samples of marine invertebrates}

A total of 215 samples of marine sponges, 99 samples of ascidians, 15 samples of bryozoans and
20 samples of octocorals were collected during 1995 - 1999, 2001 and 2002, mostly over hard surfaces at more than 60 stations along the Brazilian southeastern coastline (São Sebastião district, State of São Paulo and Arraial do Cabo, State of Rio de Janeiro) as well as along the northeastern Brazilian coastline (Baía de Todos os Santos, Salvador, State of Bahia). Sites at the State of São Paulo coastline included the São Sebastião island (Ilhabela), São Sebastião Channel, Cabelo Gordo de Fora Beach, Barequeçaba rocky shore, Toque Toque Island, Vitoria Island, Búzios Island, Montão de Trigo Island and Alcatrazes Archipelago. Collecting sites at Arraial do Cabo, State of Rio de Janeiro were realized at the Cabo Frio Island: Ponta do Anequim; Porcos Island; Saco do Cherne; Forno Beach; Saco dos Ingleses; Saco do Cardeiro; Racha de Nossa Senhora; Ponta Leste. Collecting stations at the Baía de Todos os Santos, Salvador, State of Bahia, included: Forte de Santa Maria, Porto da Barra; Ponta de Mont Serrat, Brakewater North; off Cantagalo Beach; Pier of Itaparica Island; Brakewater Port Harbour. Vouchers of sponges, octocorals and bryozoans are deposited in the collection of the Museu Nacional, Universidade Federal do Rio de Janeiro. Vouchers of ascidians are deposited in the collection of the Deparamento de Zoologia, Universidade Federal do Paraná. Complete species identifications of these vouchers will be generated in parallel to the future chemical scrutiny of selected samples. Voucher code numbers of all species are provided in Tables 1 - 3 .

\section{Crude extracts}

All animals were frozen shortly after collection, with the exception of those collected at Arraial do Cabo, RJ, which were immediately stored in 95\% EtOH. Approximately $50 \mathrm{~g}$ of each frozen invertebrate sample was defrost before immersion in $100 \% \mathrm{MeOH}$, chopped and left overnight. The extracts were filtered and evaporated in vacuo. Tightly closed samples were carefully sealed with Parafilm ${ }^{\circledR}$ and stored at $-20^{\circ} \mathrm{C}$ until needed.

\section{Antimicrobial assay}

Bacterial and yeast plates were prepared according to Nascimento et al. (2000). Bacterial strains included: Pseudomonas aeruginosa (ATCC 27583), Escherichia coli (ATCC 259222), Staphylococcus aureus (ATCC 25923), Enterococcus faecalis (ATCC 29212), Salmomella cholaraesusis (ATCC 10708), and the yeast Candida albicans (ATCC 10231). The following resistant strains, isolated from the Piracicaba city hospital, state of São Paulo, Brazil were also used in the antibacterial assay: Enterobacter sp. \#1.17.b, Proteus sp. \#6.3, E. coli \#9, E. cloacae, S. aureus \#2.12. a , S. aureus \#8, S. aureus \#18, S. aureus \#68, S. aureus \#115 and S. aureus \#134. 
Crude extracts were subjected to the antibacterial bioassay following our previously reported procedure (Torres et al., 2002a). Briefly, bacteria were grown in BHI (Brain Heart Infusion) liquid medium at $37^{\circ} \mathrm{C}$. After 6 hours of growth, each microorganism was inoculated on the surface of Mueller-Hinton agar plates at a concentration of $10^{6}$ cells $/ \mathrm{mL}$. Subsequently, previously sterilized filter paper discs (6 $\mathrm{mm}$ in diameter) were impregnated with $20 \mu \mathrm{L}$ of a $400-500 \mu \mathrm{g} / \mathrm{mL}$ solution of each crude extract and were placed on the surface of inoculated plate (agar diffusion method). The plates were incubated at $37^{\circ} \mathrm{C}$ for 24 hours. Zones of growth inhibition greater than $7 \mathrm{~mm}$ were considered susceptible to crude extracts.

\section{Antimycobacterial activity against Mycobacterium tuberculosis H37Rv}

The antimycobacterial activity of crude extracts was assayed against Mycobacterium tuberculosis H37Rv ATCC 27294 by the microplate Alamar Blue assay (Collins and Franzblau, 1997). Mycobacteria were grown on Loweinstein-Jensen medium at $37^{\circ} \mathrm{C}$ and the concentration adjusted to a bacterial density corresponding to 1.0 McFarland turbidity standard $\left(1 \times 10^{7}\right.$ cell $\left./ \mathrm{mL}\right)$, that was further diluted $1: 25$ in Middlebrook 7H9 broth medium before the inoculation $\left(4 \times 10^{5}\right.$ mycobacteria/mL). Stock solutions of the crude extracts were diluted in DMSO at concentrations ranging from 1.0 to $80 \mu \mathrm{g} / \mathrm{mL}$, sterilized by passage through a $0.22 \mu \mathrm{m}$ PFTE filter (Millex-FG, Millipore) and diluted 1:10 in Middlebrook 7H9 broth. The diluted samples were aliquoted and all the samples were stored at $-20^{\circ} \mathrm{C}$ until necessary. Serial dilutions (of the 1:10 solution) were performed in Middlebrook 7H9 broth medium, in a microplate of 96 wells, to obtain $100 \mu \mathrm{L}$ of solution in each well. The higher concentration of DMSO was 2.5\%. M. tuberculosis H37Rv was added to each well containing the samples and the microplate incubated at $37^{\circ} \mathrm{C}$ in a humidified chamber. Control wells consisting of either M. tuberculosis only (MB) or medium only (M), as well as those containing crude extract samples $(100 \mathrm{~mL})$ ranging from 0.01 to $2.0 \mathrm{mg} / \mathrm{mL}$, were inoculated with $100 \mu \mathrm{L}$ of a diluted suspension of $M$. tuberculosis $(4 \times 105$ cell $/ \mathrm{mL})$. The microplate was incubated at $37^{\circ} \mathrm{C}$ for 6 days. Afterwards, $25 \mathrm{~mL}$ of a mixture $1: 1(\mathrm{v} / \mathrm{v})$ of $10 \mathrm{x}$ Alamar Blue reagent and $10 \%$ Tween 80 were added to the wells and the plates were reincubated at $37^{\circ} \mathrm{C}$. After 24 hours, a change in color from blue to pink was observed in the wells where the mycobacteria grew. The visual minimal inhibitory concentration (MIC) were defined as the lowest drug concentration which prevented a color change from blue to pink. Rifampicin was used as a standard.

Inhibition of Leishmania tarentolae adenine phosphoribosyltransferase (L-APRT)

290 Rev. Bras. Farmacogn.

Braz J. Pharmacogn.

17(3): Jul./Set. 2007
The inhibition of L-APRT was performed following a modified protocol described by Tuttle and Krenitsky (1980). The rate of absorbance change resulting from the conversion of 5'-phospho- $\alpha-\mathrm{D}$ ribosyl-1'-pyrophosphate (PRPP, $100 \mathrm{mM}$ ) and adenine $(100 \mathrm{mM})$ to adenine 5'-monophosphate (AMP) catalyzed by adenine phosphoribosyltransferase (APRT) in $5 \mathrm{mM} \mathrm{MgCl}{ }_{2}$ containing Buffer Tris- $\mathrm{HCl} \mathrm{pH}$ 7.4, $100 \mathrm{mM}$, was monitored spectrophotometrically at $259 \mathrm{~nm}$ in a final volume of $0.5 \mathrm{~mL}$. The reaction was started by the addition of $1 \mathrm{~mL}$ of the enzyme solution and monitored during 1 minute. The rate of increase in AMP formation, in presence of natural substrates, was used to calculate the APRT specific activity (AMP molar absorbancy 15.4 x 103). The screening with crude extracts was performed with a final concentration of 50 $\mu \mathrm{g} / \mathrm{mL}$ of the test sample.

\section{Cytotoxicity assays}

MCF-7 (breast), B16 (melanoma) and HCT8 (colon) cancer cell lines were obtained from the Children's Mercy Hospital, Kansas City, MA. The microtiter assay for cytotoxicity was performed using the sulforodamine B (SRB) method (Skehan et al., 1990), according to the following procedure. Each assay consisted of four 96-well microplates, one for each cell line (MCF-7, B16 and HCT-8) and one plate for the zero-time with the three cell lines. Adherent cancer cells (B16, MC-7 and HCT8) at a concentration of 0.3 x $10^{6}$ cells $/ \mathrm{mL}$ were seeded in 96 -well microplates. The adherent cells were incubated for 24 hours to allow cell attachment. After 24 hours incubation, the zero time microplate was fixed with chilled $50 \%$ trichloroacetic acid, and the other microplates were incubated in the presence of test samples at $125 \mu \mathrm{g} / \mathrm{mL}$. The samples were tested in duplicate. Etoposide $(500 \mathrm{ng} / \mathrm{mL}$ ) was utilized as positive control. These microplates were fixed after 48 hours of incubation with the standard and crude extracts. All the microplates were stained with sulforodamine B and the cell concentration was estimated in a multiwell scanning spectrophotometer at $540 \mathrm{~nm}$. The percentage of cell growth $(\% \mathrm{G})$ was calculated by comparing the absorbance of test samples with the control (100\%), zero-time (0\%) and the cytotoxic standard etoposide ($100 \%)$. The fractions were classified as possessing no activity (blank space), low activity (those that produced up to $50 \%$ growth inhibition, + ), moderate activity (those that produced between $50 \%$ and $75 \%$ growth inhibition, ++ ), and high activity (those that produced greater than $75 \%$ growth inhibition, +++ ) for each cell line tested.

\section{RESULTS}

\section{Marine sponges}

Table 1 shows the biological activities 
observed for the crude extracts of the 215 sponge samples analysed. The results presented in Table 1 are summarized in Figures 1 and 5, where the overall pattern of the biological activity observed for crude extracts of marine sponges can be evaluated. Less than $3 \%$ of the marine sponge crude extracts displayed activity against S. aureus resistant strain 2.12a, Enterobacter sp., Proteus sp. and C. albicans (Figure 1). More than 15\% of the crude extracts were active against susceptible $S$. aureus ATCC 25923, E. coli ATCC 25922 and three S. aureus oxacillin-resistant strains (\# 108, 115 and 135), while 10 to $15 \%$ of the marine sponge crude extracts displayed activity against other bacteria. Up to $40 \%$ of the marine sponge crude extracts displayed antimycobacterial activity against $M$. tuberculosis H37Rv. Cytotoxicity was observed for 8 to $18 \%$ of the marine sponge crude extracts. Up to $18 \%$ of cytotoxic extracts displayed activity against HCT-8 colon cancer cells, $11 \%$ presented cytotoxicity against MCF-7 breast cancer cells, while $8 \%$ are active against B16 murine melanoma cancer cells. Less than $3 \%$ of the marine sponge crude extracts displayed activity against L-APRT (Figure 1).

\section{Ascidians}

Table 2 shows 99 ascidian samples and their respective bioactivity profile, which is summarized in Figures 2 and 5 . While $8 \%$ of ascidian crude extracts were active against S. aureus ATCC 6538, less than 5\% of ascidians crude extracts displayed antibacterial activity against seven of the 15 human bacterial pathogens used in the present screening [antibiotic-resistant $S$. aureus 2.12a, E. coli ATCC 25922, P. aeruginosa resistant strain \# 6.4, Enterobacter sp. resistant strain \# 1.17b, Proteus sp. resistant strain \# 6.3 and two $S$. aureus oxacilin-resistant strains (\# 68 and \#115)], being inactive against eight of the bacterial strains. Up to $28 \%$ of ascidians crude extracts displayed activity against M. tuberculosis H37Rv. Ascidian crude extracts also displayed significant cytotoxic activity against three cancer cells: almost 15\% against MCF-7 breast cancer cells, 30\% against HCT-8 colon cancer cells and almost $10 \%$ against B16 murine melanoma cancer cells. Two percent of ascidian crude extracts displayed inhibitory activity on L-APRT.

\section{Bryozoans and Cnidarians}

The number of bryozoan (15) and octocoral (20) samples obtained was by far smaller than the number of marine sponges and ascidians (Table 3). Therefore, the general trends observed for the biological activity profile of these two groups of marine invertebrates should be evaluated with caution. Only one bryozoan crude extract displayed activity against two bacterial strains, S. aureus ATCC 25923 and S. aureus oxacilinresistant strain \# 108 (Table 3 and Figure 3). Up to 60\% of bryozoan crude extracts displayed antimycobacterial activity, $13 \%$ displayed cytotoxic activity against MCF7 and 20\% displayed cytotoxic activity against HCT8 cancer cells. Only one bryozoan extract was active against L-APRT (Table 3 and Figure 3).

Less than $10 \%$ of the crude extracts from gorgonians (Octocorallia) displayed antibiotic activity against seven of the 16 bacterial strains used in this screening. Up to $60 \%$ of octocoral crude extracts presented antimycobacterial activity, and c.a. 30\% of crude extracts displayed cytotoxic activities (Table 3 and Figure 4).

The overall bioactivity profile of the marine invertebrate crude extracts herein investigated indicate that $28 \%$ of sponge crude extracts, $40 \%$ of ascidian crude extracts, $13 \%$ of bryozoan crude extracts and $25 \%$ of octocoral crude extracts did not display any activity in the bioassays (Figure 5). The large majority of crude extracts was active in 1 to 5 bioassays, with a much smaller number of extracts active in more than 6 bioassays. It is interesting to note that, when antibiotic activity is expressed by extracts obtained from any of the four group of invertebrates, it is in general of low potency. On the other hand, antimycobacterial and cytotoxic activities are in general of much higher potency (see Figures 1 to 4 ).

\section{DISCUSSION}

\section{Marine sponges}

Several screening investigations demonstrated that crude extracts from marine sponges display potent antibiotic (Ely et al., 2004; Xue et al., 2004) cytotoxic (Prado et al., 2004) as well as various biological activities (Selvin and Lipton, 2004). However, only a limited number of sponge samples have been screened. Also recently, a biological screening related the activities of sponge extracts from samples collected in tropical (Guam) and temperate (Indo-Pacific and Mediterranean) biogeographical areas, but of a limited number (20) of sponge species (Becerro et al., 2003). Therefore, it is of interest to screen a large number of sponge extracts, in order to verify the percent of active extracts and the relatedeness with the taxonomy of the sponges which yielded the most active crude extracts.

Table 1 and Figure 1 show that, in average, 15\% of the crude extracts of 215 sponges samples tested in the present screening were active in all but one bioassay (activity against the bacterial strain Proteus sp.). The graph of Figure 5 shows that the majority of marine sponge crude extracts (54\%) displayed activity in 1 to 5 bioassays used in the present investigation. This result is in agreement with previous pharmacological evaluations that demonstrate that marine sponges very often present biologically active secondary metabolites (Blunden, 2001; Cragg and Newman, 2001; Faulkner, 2000a;

Rev. Bras. Farmacogn. Braz J. Pharmacogn 17(3): Jul./Set. 2007 
Haefner, 2003; Jack, 1998; Kerr and Kerr, 1999; Mayer and Hamann, 2002; Munro and Blunt, 2007; Newman et al., 2003; Peng et al., 2003; Proksch et al., 2002; Quinn et al., 2002; Takamatsu et al., 2003; De Vries and Beart, 1995). As shown in graph of Figure 1, more than $10 \%$ of all sponge crude extracts display antibiotic activity against most of microbial strains used in this screening, with exception against Staphylococcus aureus resistant strain \# 2.12a, Enterobacter sp. resistant strain \# 1.17.b, Proteus sp. resistant strain \# 6.3 and Candida albicans ATCC 10231. This result clearly indicates that marine sponges constitute an important source of antibiotic agents, including compounds active against resistant bacterial strains. Noteworthy is the percent of sponge extracts (40\%) active against $M$. tuberculosis H37Rv. Only recently marine sponges have started to be investigated for the search for new antituberculosis agents, for which they show to be a promising source of new drugs for the treatment of tuberculosis (Copp, 2003; El Sayed et al., 2000; Donia and Hamann, 2003). A smaller percentage of sponge extracts displayed cytotoxic activity against MCF-7 breast cancer cells (11\%), HCT-8 colon cancer cells (18\%) and B16 murine melanoma cancer cells (8\%). However, these results are in agreement with results obtained in previous large screenings carried out at the National Cancer Institute of the USA (Garson, 1994). A much smaller percent (3\%) of sponge extracts displayed inhibitory activity against L-APRT.

Considering the relatedness between taxonomy and biological activity profile of the marine sponge samples in this investigation, some features can be observed. Our results indicate that four out of nine samples of sponges belonging to the genus Aaptos present biologically active compounds. Marine sponges belonging to the genus Aaptos are known as producers of 1H-benzo-[de][1,6]-naphtyridine alkaloids, a group of compounds which display several biological activities (Granato et al., 2000; Nakamura et al., 1982; Nakamura et al., 1987; Rudi and Kashman, 1993; Tinto, 1998; Longley et al., 1993; Shen et al., 1999; Coutinho et al., 2002; Takamatsu et al., 2003), and, therefore, compounds related to the aaptamines may be present in the samples of marine sponges herein investigated. Among them, the sponge sample Aaptos BA99-52 showed good antibacterial activity activity against oxacilin resistant $S$. aureus strain \# 35.

Marine sponges belonging to the order Verongida, such as those of the genus Aplysina, are considered the major source of bromotyrosinederived alkaloids, compounds that often exhibit potent biological activities (reviewed in Rao et al., 2000). In our present screening, two samples of Aplysina spp. displayed activity in ten or more bioassays, and three additional samples displayed specific activity in one to two bioassays. Moreover, of the thirteen Aplysina species evaluated, four (BA99-24, BA99-26, BA99-60 and BA99-69) displayed moderate antimycobacterial activity with MIC between 201 and $400 \mu \mathrm{g} / \mathrm{mL}$. It has been recently reported that bromotyrosine-derived compounds, such as psammaplin A, strongly inhibit Mycobacterium tuberculosis detoxification enzyme mycothiol-S-conjugate amidase (Nicholas et al., 2002; 2003). We have recently started to investigate the chemistry of Brazilian Verongida sponges, aiming the isolation of biologically active bromotyrosine derivatives. Crude extracts of the Brazilian endemic Aplysina caissara (samples SS98-34 and SS99-4) displayed mild antibacterial and cytotoxic activities. The subsequent chemical investigation of this sponge led to the isolation of two new secondary metabolites, namely caissarine A (1) and caissarine B (2), along with three already known bromotyrosine derivatives (Saeki et al., 2002). Our subsequent re-investigation of $A$. caissara yielded additional bromotyrosine-derivatives with antibacterial activity (Lira et al., 2006). Furthermore, the crude extract of Aplysina sp. BA99-26, later identified as $A$. cauliformis, displayed antimycobacterial activity against $M$. tuberculosis. The active compounds were isolated and identified as the known (+)-fistularin- 3 and 11-desoxyfistularin-3 (Oliveira et al., 2006a). Currently the Aplysina spp. BA99-24, BA99-60 and BA99-105 are under investigation towards the isolation of bioactive compounds present in the crude extracts.

Sponges of the order Haplosclerida, such as those belonging to genera Callyspongia, Haliclona, Niphates and Pachychalina, are a remarkable source of bioactive alkylpyridine and alkylpiperidine alkaloids (reviewed in Andersen et al., 1996; Almeida et al., 1997; Berlinck, 2007). In our screening, sponges of these four genera yielded active crude extracts in several of the bioassays, some of them with a high activity level. Callyspongia sp BA99-115 showed an hali of inhibition higher than $15 \mathrm{~mm}$ on $S$. aureus oxacilinresistant strains \# 36 and \# 63. Haliclona sp SS97-36 was highly cytotoxic on HCT-8 colon cancer cells. The crude extract of Niphates sp BA99-51 displayed high antibacterial level against $S$. aureus oxacilin-resistants strains \# 36, \# 61 and \# 63, while the crude extract of Niphates sp. BA99-71 displayed potent antibiotic activity against oxacilin resistant $S$. aureus (strain \# 35). Different samples of Pachychalina sp. presented biological activities. Sample SS02-12 was very effective against E. coli ATCC 25922 and M. tuberculosis H37Rv, while samples SS02-14 and SS02-23 were effective only against $M$. tuberculosis H37Rv. We have performed the chemical investigation of Pachychalina sp. SS02-12, and have obtained the new ingenamine $G$ alkaloid (3), which displayed cytotoxic, antimycobacterial and antibiotic activities (Oliveira et al., 2004), cyclostellettamines A-I, $K$ and $L$ (4-14), which showed antibacterial, antifungal and antimycobacterial activities (Oliveira et al., 2004; Oliveira et al., 2006b), as well as haliclonacyclamine F (15), madangamine $F$ (16) and arenosclerins D 
(17) and E (18), which displayed cytotoxic activities (Oliveira et al., 2007). Another haplosclerid sponge, Callyspongia sp. SS97-23, yieled a crude extract which displayed cytotoxic activity against HCT-8 colon cancer cell line and inhibitory activity of L-APRT. The active constituents have been subsequently identified as the meroterpenoids ilhabelanol (19), ilhabrene (20) and isoakaterpin (21) as the most potent inhibitors of LAPRT isolated so far (Gray et al., 2006). We are currently investigating the bioactive chemical constituents of additional Haplosclerida sponges, such as Niphates sp. BA99-70 and Callyspongia sp. BA99-106.

Crude extracts of eight samples of Cliona spp. have been evaluated in our screening, two (SS98-8 and SS02-35) of which were highly active against $M$. tuberculosis H37Rv and another (BA99-44) showed high activity against $S$. aureus oxacilin-resistant strains 36 and 115 (Table 1). This is the first report of Cliona spp. crude extracts active against $M$. tuberculosis and antibiotic resistant bacteria. Cliona species have usually yielded modified cytotoxic peptides and alkaloids, such as clionamides (Andersen and Stonard, 1979).

Dysidea sponges have long been known as a prolific source of bioactive natural products (Sharma and Vig, 1972). Representative classes of secondary metabolites isolated from Dysidea sponges include several classes of terpenes, modified peptides and diketopiperazines with uncommon amino acids, bromodiphenyl ethers, and, less frequently, alkaloids. In our screening, four (BA99-108, BA99-111, BA99114 and AC01-02) out of the eleven samples of Dysidea yielded crude extracts strongly active against $S$. aureus ATCC 6538, E. coli ATCC 25922, S. aureus oxacilinresistant strain \# 61 and $M$. tuberculosis H37Rv microbial strains, as well as against MCF-7 breast and HCT-8 colon cancer cells. Several of the Dysidea samples screened here are probably conspecific with $D$. etheria, a very common species at Salvador and at Arraial do Cabo. The repetitive presence of a same species could also be verified not only by taxonomical analysis but also by a similar bioactivity profile for samples AC01-10, BA9917, SS02-30 and SS02-31. Currently, we are aiming the isolation of bioactive constituents from Dysidea spp. BA99-38, BA99-108, BA99-111 and BA99-114.

Crude extracts of two sponges assigned to Darwinella genus displayed high antimicrobial activity against E. coli ATCC 25922, Pseudomonas aeruginosa resistant strain \# 6.4, S. aureus oxacilin-resistants strains \# 35, \# 36 and \# 115, and were less active against $S$. aureus oxacilin-resistant strains \# 18, \# 61, \# 63, \# 108 and \# 135. However, these same extracts showed low cytotoxic level on cancer cell lines and are now being investigated in respect to toxicity on mammalian cells. Strong antibiotic and antimycobacterial activities are being reported for the first time for the genus.

Sponges of the genus Ircinia are well known producers of furano- or tetronic acid-bearing sesterterpenes and related compounds, which very often present antibiotic activity (reviewed in Blunt et al., 2007). Our screening results indicate that three (BA9957, BA99-107 and BA99-124) samples of Ircinia displayed good antibacterial activity on $S$. aureus ATCC 6538, E. coli ATCC 25922 and on S. aureus oxacilinresistant strain \# 61, as well as weak activity on the others bacterial strains. The crude extract of sponge Ircinia sp. BA99-57 is now under investigation.

All four samples of Monanchora spp. (BA9923, BA99-25, BA99-48 and BA99-125) obtained yielded the most active crude extracts tested in our screening. The extracts analysed here showed strong antibacterial, antimycobacterial and cytotoxic activities, probably due to the presence of guanidine alkaloids tipically isolated from Monanchora spp. and other Poescilosclerida sponges (reviewed in Berlinck and Kossuga, 2005; Berlinck and Kossuga, 2007). Up to the present, only isoptilocaulin (22) has been isolated from Monanchora sp. BA99-125 (Kossuga et al., in press, 2007). This far, only one species of Monanchora is recognized as valid in the tropical western Atlantic, viz. M. arbuscula (Duchassaing and Michelotti). Its alleged large morphological plasticity (Van Soest et al., 1996) is nevertheless suggestive that a complex of species may exist instead. It is thus worth comparing chemical and biological activity profiles from populations of distinct geographic localities, coupled with a detailed taxonomic study of these sponges.

Three out of six species of sponges belonging to the genus Mycale (SS97-37, SS97-59 and AC0106) yielded active extracts. Mycale sponges are known producers of an array of different bioactive secondary metabolites, including unusual nucleosides, terpenes, highly functionalized polyketides, as well as macrolide and pyrrole alkaloids (Blunt et al., 2007).

The marine sponge Petromica sp. BA99-103 yielded a crude extract active as inhibitor of L-APRT. A bioassay-guided chemical investigation of this extract led to the isolation of halistanol sulfate (23) as the main L-APRT inhibitor (Kossuga et al., 2007).

Surprisingly, the samples of Agelas sp. herein investigated did not yield any bioactivity, in spite of the genus remarkable occurrence of pyrrole and guanidine bearing alkaloids (Berlinck and Kossuga, 2005; Blunt et al., 2007).

Crude extracts of sponges of the genus Petrosia, Placospongia, Plakortis, Polymastia, Ptilocaulis, Scopalina, Spongia, Stelleta, Suberites, Terpios, Thethya, Timea, Topsentia, Toxocalina and Trachicladus showed no antibacterial activity or displayed halii of inhibition between 5 and $10 \mathrm{~mm}$ against a few bacteria strains. However, among these sponges, samples AC0106, SS97-20, SS02-12, SS02-14, SS02-15, SS02-23 and BA99-112 were active against $M$. tuberculosis H37Rv with MIC between 101 and $200 \mu \mathrm{g} / \mathrm{mL}$. One sponge of the genus Tedania (AC01-08) presented inhibition of 
the growth of $S$. aureus oxacilin-resistant-strain \#11 with a hali higher than $15 \mathrm{~mm}$.

Sponge samples SS98-33, SS02-23, BA9950, BA99-10, BA99-49, BA99-13, BA99-110 and BA99-112 showed significative cytotoxic activity on all tumoral cell lines.

\section{Ascidians}

Table 2 and Figure 2 shows that up to $28 \%$ of crude extracts from ascidians displayed antimycobacterial activity, ca. $15 \%$ of the crude extracts from ascidians displayed cytotoxic activity and less than $5 \%$ of the crude extracts were active against bacteria and fungi. Additionally, the majority of ascidians crude extracts (60\%) displayed activity in one to five bioassays used in the present investigation (Fig. 5). As in the case of marine sponges, it has been extensively reported that ascidians frequently have a rich secondary metabolism of bioactive compounds (Blunden, 2001; Cragg and Newman, 2001; Faulkner, 2000b; Haefner, 2003; Jack, 1998; Kerr and Kerr, 1999; Mayer and Hamann, 2002; Munro and Blunt, 2007; Newman et al., 2003; Peng et al., 2003; Proksch et al., 2002; Quinn et al., 2002; Takamatsu et al., 2003; De Vries and Beart, 1995).

Twenty of the ninety nine samples of ascidians collected for our screening belong to the cosmopolitan genus Didemnum, a well known source of a number of biologically active compounds such as the potent cytotoxic tamandarin A from a Brazilian Didemnum (Vervoort et al., 2000) and the G2 cell cycle checkpoint inhibitor isogranulatimide from Didemnum granulatum (Berlinck et al., 1998; Roberge et al., 1998). Ascidians of the genus Didemnum are a common source of cytotoxic compounds, but other biological activities have also been reported for Didemnum spp. secondary metabolites. Among the ascidians belonging to the family Didemnidae herein investigated, two samples of the genus Polysyncraton displayed cytotoxic activity and inhibition of Leishmanial APRT. Other ascidian genera which displayed potent cytotoxic activity in our screening include Clavelina, Aplidium (Order Aplousobranchia), Herdmania, Microcosmus (Order Stolidobranchia, Pyuridae), Eusynstyela, Botrylloides, and Symplegma (Order Stolidobranchia, Styelidae). Therefore, the results of our screening are not surprising, since ascidians very often present natural products with significant cytotoxicity (Watters and van den Brenk, 1993; Davidson, 1993; Garson, 1994; Sings and Rinehart, 1996; Rinehart, 2000). We have recently studied the cytotoxic crude extract of the ascidian Cystodytes dellechiajei SS97-16, and obtained two pyridoacridine alkaloids, sebastianine A (24) and B (25) (Torres et al., 2002b). Our recent chemical investigation of the antibiotically active crude extract of Clavelina oblonga SS96-01 yielded (2S,3R)-2-aminododecan-3-ol (26) strongly active against the fungi Candida albicans
(Kossuga et al., 2004). We are currently investigating the bioactive metabolites from the crude extracts of Polysyncraton spp. SS95-3 and SS97-2, as well as of Didemnum sp. BA99-5.

\section{Bryozoans and Cnidaria}

Two bryozoans of the genus Bugula and another unidentified sample yielded highly cytotoxic crude extracts, whereas another seven bryozoan species yielded moderately cytotoxic crude extracts. Considering that only fifteen crude extracts were obtained from samples of bryozoans, the percentage of potent cytotoxic extracts was high. A similar result was observed during a screening at the National Cancer Institute (Garson, 1994). Bryostatins are the best known examples of a bryozoan secondary metabolites with potent cytotoxic activities, of which bryostatin 1 is currently in clinical trials (Pettit, 1991; Mutter and Wills, 2000; Hale et al., 2002).

The large majority of the octocoral crude extracts also displayed potent cytotoxic and antimycobacterial activity in our screenings. The two genera which could be assigned to the identified gorgonians, Carijoa and Lophogorgia, presented extracts with high cytotoxic activity. Previous chemical investigations of gorgonians belonging to these two genera led to the isolation of a plethora of bioactive natural products, such as riiseins $\mathrm{A}$ and $\mathrm{B}$, cytotoxic sterol glycosides isolated from Brazilian samples of Carijoa riisei (Maia et al., 2000) and lophotoxin, a potent neurotoxin from Lophogorgia sp. (Fenical et al., 1981). Our sample of Carijoa riisei SS97-34 yielded the known steroid $\mathbf{2 7}$ as the only cytotoxic compound present in the crude extract (Kossuga et al., 2007).

\section{CONCLUSION}

As an overall trend observed in the results herein reported, a larger percentage of sponge extracts were active against microbials (Figure 1) when compared to ascidian extracts (Figure 2). This result is rather unexpected, since the percentage of antibiotic compounds isolated from ascidians is comparable with the number of antibiotic compounds isolated from marine sponges. For example, a search in the MARINLIT literature database (Blunt et al., 2007) including the parameters “Ascidiacea” and "antibiotic” yielded 115 structures (corresponding to $12.7 \%$ of 906 compounds isolated from Ascidiacea) and 137 bibliographic records (corresponding to $11.2 \%$ of 1,216 records assigned for Ascidiacea), whereas a search including the parameters "Porifera" and "antibiotic" gave comparable percentage results (898 antibiotic compounds, corresponding to $13.7 \%$ of a total 6,541 structures isolated from Porifera; and 650 bibliographic records, corresponding to $11.7 \%$ of a total 5,569 Porifera literature records). 
The reason why ascidian crude extracts displayed much less antibiotic activity than sponges crude extracts in the present investigation is not clear. The same general profile is observed for bryozoans and octocorals crude extracts. Overall, ascidians, bryozoans and octocorals crude extracts presented a much higher level of antituberculosis and cytotoxic activities in the present investigation (Figures 2, 3 and 4).

Considering the total number of crude extracts subjected to all bioassays, only a very small number (eight) displayed inhibitory activity against Leishmania tarentolae adenine phosphoribosyl transferase (LAPRT). This result was expected, since this is an enzyme based assay, which normally requires highly specific inhibitors (Grabley and Thiericke, 1999; Patrick, 2001).

In conclusion, our screening results agree with previous screenings of marine invertebrates crude extracts, which showed that marine sponges, ascidians, bryozoans and octocorals frequently present biologically active secondary metabolites (Garson, 1994). The subsequent chemical investigation of crude extracts from marine invertebrates screened in this investigation led to the isolation of several biologically active compounds (Berlinck et al., 2004; Gray et al., 2006; Torres et al., 2002b; Saeki et al., 2002; Oliveira et al., 2004; Oliveira et al., 2006a; Oliveira et al., 2006b; Kossuga et al., 2004; Kossuga et al., 2007). Continuing studies of secondary metabolites of these and other softbodied marine invertebrates will certainly yield several new bioactive molecules, which may be envisaged as new leads in drug-discovery programs (Berlinck et al., 2004). Therefore, the importance of carefully managing ocean natural resources should not be overlooked, not only for conservation purposes, but also in order to preserve and evaluate the economic potential of marine natural products.

\section{ACKNOWLEDGMENTS}

The authors thank Professor Raymond J. Andersen and Michael LeBlanc (Department of Earth and Ocean Sciences, University of British Columbia, Vancouver, Canada), Chris M. Ireland, Brent Lindsay, Louis Barrows (Department of Medicinal Chemistry, University of Utah, Salt Lake City, United States of America), Marcio R. Custódio, U. S. Pinheiro (Centro de Biologia Marinha and Instituto de Biocências, Universidade de São Paulo), Josiane H.G. da Rocha, Maíra V. de Oliveira, Mariana de S. Carvalho, Cristina P. Santos, Eduardo P. Vilanova and Suzi M. Ribeiro (Museu Nacional, UFRJ), Rafael Metri (Departamento de Zoologia, UFPR) and James Roper (Universidade Tuiuti do Paraná) for their help and assistance during several field trips for invertebrate collections. Chris M. Ireland is further thanked for providing underwater photography and satellite positioning facilities to $\mathrm{EH}$ and
RGSB. Professors Maria da Glória B. S. Moreira, José C. de Freitas and Eleonora Trajano, are acknowledged for the many facilities provided for invertebrate collection near to Centro de Biologia Marinha of the Universidade de São Paulo. Financial support to RGSB was provided by Fundação de Amparo à Pesquisa do Estado de São Paulo grants (94/0179-8, 96/04316-5 and 01/03095-5), by American Society of Pharmacognosy Foundation research Starter Grant (1998) and a NIH grant CA 67786. Financial support to EH and GM has been provided by CNPq and FAPERJ grants, while support to RMR was provided by CNPq.

\section{REFERENCES}

Aceret TL, Sammarco PW, Coll JC, Uchio Y 2001. Discrimination between several diterpenoid compounds in feeding by Gambusia affinis. Comp Biochem Physiol 128C: 55-63.

Almeida AMP, Berlinck RGS, Hajdu E 1997. Alcalóides alquilpiridínicos de esponjas marinhas. Quim Nova 20: 170-185.

Amsler CD, Iken KB, McClintock JB, Baker BJ 2001. Secondary metabolites from Antarctic marine organisms and their ecological implications. In: McClintock JB and Baker JB (Eds.) Marine Chemical Ecology, Boca Raton, CRC Press, p. 267-300.

Andersen RJ, Stonard R 1979. Clionamide, a major metabolite of the sponge Cliona celata Grant. Can J Chem 57: 2325-2328.

Andersen RJ, van Soest RWM, Kong F 1996. 3-Alkylpiperidine alkaloids isolated from marine sponges in the order Haplosclerida, In: Pelletier SW (Ed.) The Alkaloids: Chemical and Biological Perspectives. New York, Pergamon Press, Vol. 10, p. 301-355.

Bandaranayake WM, Bennis JE, Bourne DJ 1996. Ultraviolet absorbing pigments from the marine sponge Dysidea herbacea: isolation and structure of a new mycosporine. Comp Biochem Physiol 115C: 281286.

Becerro MA, Uriz MJ, Turon X 1994. Trends in space occupation by the encrusting sponge Crambe crambe: variation in shape, as a function of size and environment. Mar Biol 121: 301-307.

Becerro MA, Turon X, Uriz MJ 1995. Natural variation of toxicity in encrusting sponge Crambe crambe (Schmidt) in relation to size and environment. $J$ Chem Ecol 21: 1931-1946.

Becerro MA, Uriz MJ, Turon X 1997. Chemicallymediated interactions in benthic organisms: the chemical ecology of Crambe crambe (Porifera, Poecilosclerida). Hydrobiol 355: 77-89.

Becerro MA, Paul VJ, Starmer J 1998. Intracolonial variation in chemical defenses of the sponge Cacospongia sp. and its consequences on generalist fish predators and the specialist nudibranch predator Glossodoris pallida. Mar Ecol Prog Ser 168: 187-196.

Becerro MA, Thacker RW, Turon X, Uriz MJ, Paul VJ 2003. Biogeography of sponge chemical ecology: comparisons of tropical and temperate defenses. Oecologia 135: 91-101. 
<smiles>COC1=NO[C@@]2(C=C1Br)CC(C(=O)NCC(O)CCNC(=N)N)C(OC)=C(Br)[C@@H]2O</smiles><smiles>COC1=C(Br)[C@H](O)[C@@]2(C=C1Br)CC(C(=O)NCC(O)CCCCCNC(=O)C1=NO[C@@]3(C=C(Br)C(OC)=C(Br)[C@@H]3O)C1)=NO2</smiles>

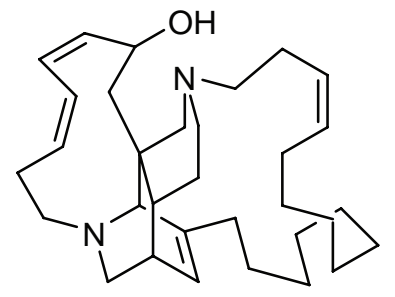

3

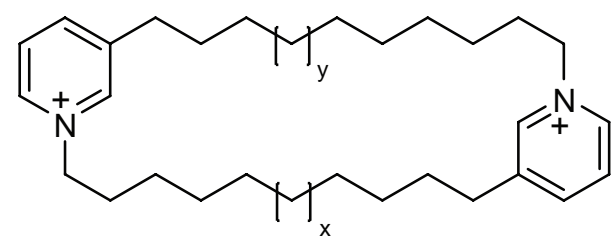

$$
\begin{array}{ll}
4 x=3, y=3 & 10 x=1, y=3 \\
5 x=3, y=4 & 11 x=2, y=3 \\
6 x=4, y=4 & 12 x=1, y=4 \\
7 x=3, y=5 & 13 x=1, y=5 \\
8 x=4, y=5 & 14 x=2, y=5 \\
9 x=5, y=5 &
\end{array}
$$

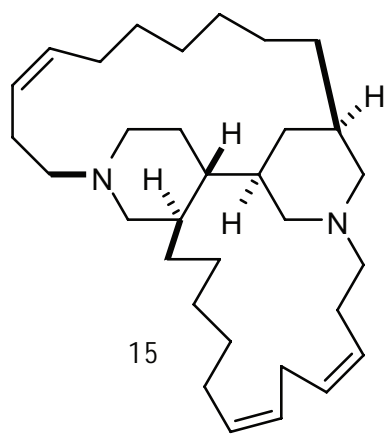

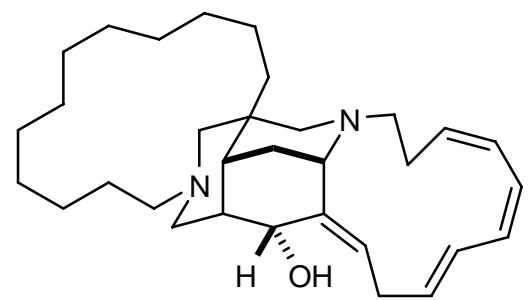

16

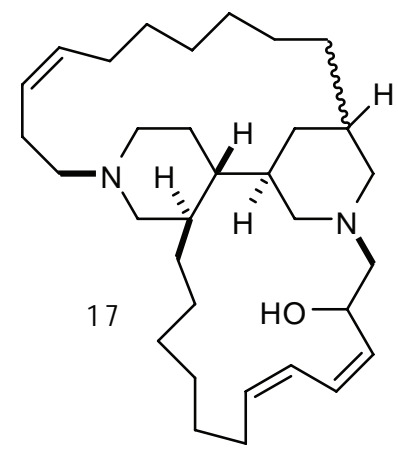

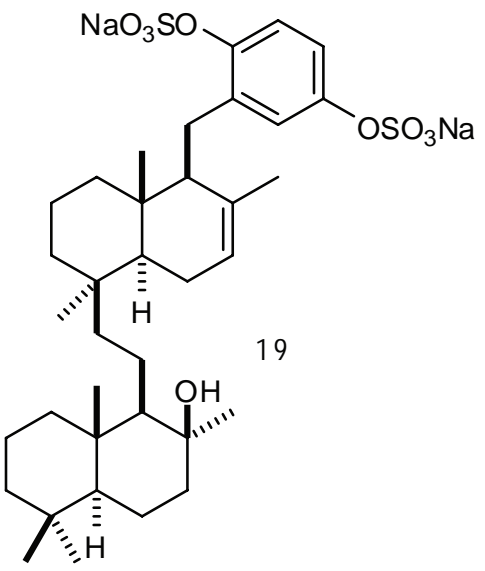<smiles>C=C1CCCC(C)(C)C1CC[C@]12CCC(=C)C(Cc3cc(OS(N)(=O)=O)ccc3OS(C)(=O)=O)C1(C)CCCC2C</smiles>

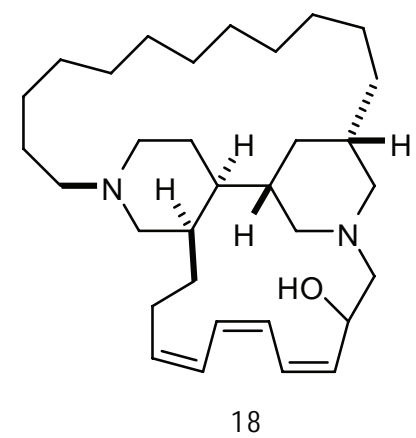

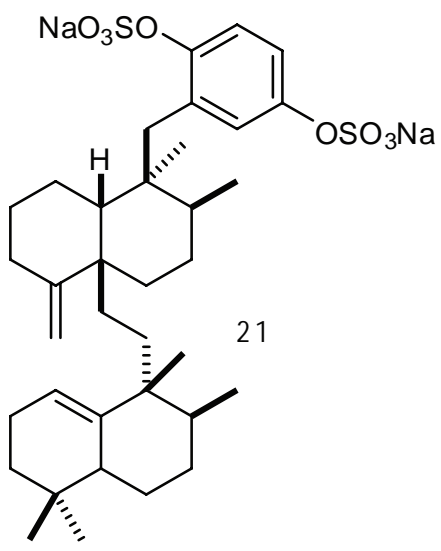


<smiles>CCCCC1=C(C)C[C@H]2CC[C@H]3NC(=[NH2+])N[C@H]1[C@@H]23</smiles>

22<smiles>CC(CCC(C)C(C)(C)C)C1CCC2C3C[C@H](OS(=O)(=O)O)C4C[C@H](OS(=O)(=O)O)C(OS(=O)(=O)O)CC4(C)C3CCC12C</smiles><smiles>O=C1c2[nH]ccc2-c2nc3ccccc3c3ccnc1c23</smiles>

23<smiles>CC(C)[C@H]1O[C@]2(O)C3=C(CCN3C1=O)c1nc3ccccc3c3ccnc2c13</smiles><smiles>CCCCCCCCCC(O)[C@H](C)N</smiles><smiles>C=CC1CCC2C3CCC4=CC(=O)C=CC4(C)C3CCC12COC(C)=O</smiles>

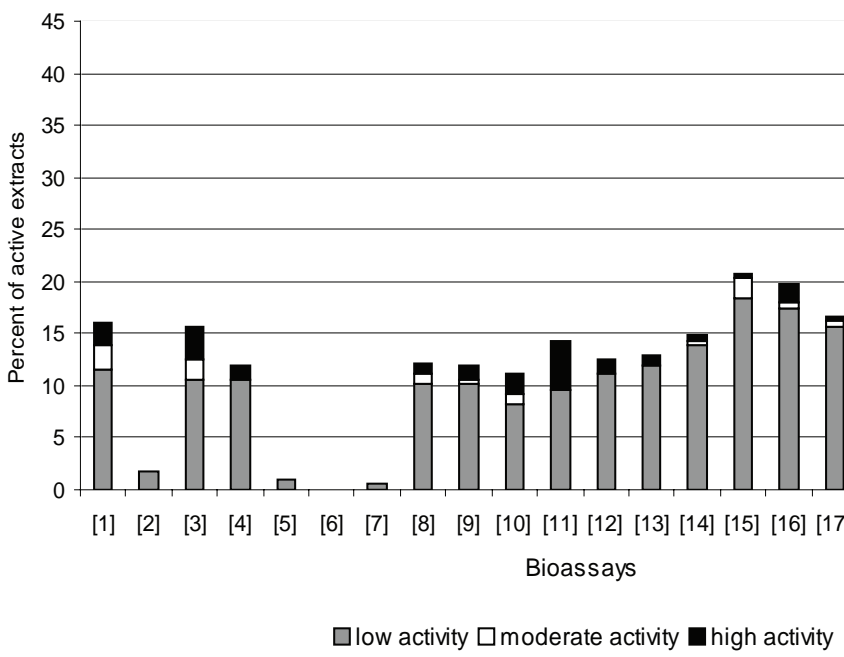

For antimicrobial bioassays: [1] = Staphylococcus aureus ATCC 6538; [2] = Staphylococcus aureus (resistant strain \# 2.12a); [3] = Escherichia coli ATCC 25922; [4] = Pseudomonas aeruginosa (resistant strain \# 6.4); [5] = Enterobacter spp (resistant strain \# 1.17.b); [6] = Proteus spp (resistant strain \# 6.3); [7] = Candida albicans (ATCC 10231); [8] = Oxacilin resistant $S$. aureus (strain \# 11); [9] = Oxacilin resistant S. aureus (strain \# 18); [10] = Oxacilin resistant $S$. aureus (strain \# 35); [11] = Oxacilin resistant $S$. aureus (strain \# 36); [12] = Oxacilin resistant $S$. aureus (strain \# 61); [13] = Oxacilin resistant S. aureus (strain \# 63); [14] = Oxacilin resistant $S$. aureus (strain \# 68); [15] = Oxacilin resistant $S$. aureus (strain \# 108); [16] = Oxacilin resistant S. aureus (strain \# 115); [17] = Oxacilin resistant $S$. aureus (strain \# 135); antibacterial activity level: + inhibition hallii $>5 \mathrm{~mm}$ and $<10 \mathrm{~mm}$; ++ inhibition halii $>11 \mathrm{~mm}$ and $<14 \mathrm{~mm}$; +++ inhibition halii > 15 mm; For antimycobacterial assay: [18] = Mycobacterium tuberculosis H37 Rv; antimycobacterial activity level: + MIC between 401 and $600 \mu \mathrm{g} / \mathrm{mL}$; ++ MIC between 201 and $400 \mu \mathrm{g} / \mathrm{mL}$; +++ MIC between 10 and $200 \mu \mathrm{g} / \mathrm{mL}$; For cytotoxic bioassays: [19] = MCF-7 breast cancer cells; [20] = HCT-8 colon cancer cells; [21] = B16 murine melanoma cancer cells; cytotoxic activity level: + inhibition up to $50 \%$ of cancer cell growth; ++ inhibition between $50 \%$ and $75 \%$ of cancer cell growth; +++ inhibition larger than $75 \%$ of cell growth; For inhibition of Leishmania tarentolae adenosine phosphoribosyl transferase bioassay [22]: + inhibition of enzymatic activity between $40 \%$ and $60 \%$; ++ inhibition of enzymatic activity between $60 \%$ and $80 \%$; +++ inhibition of enzymatic activity higher than $80 \%$.

Figure 1. Percent of marine sponge crude extracts active in each of the 22 bioassays. 


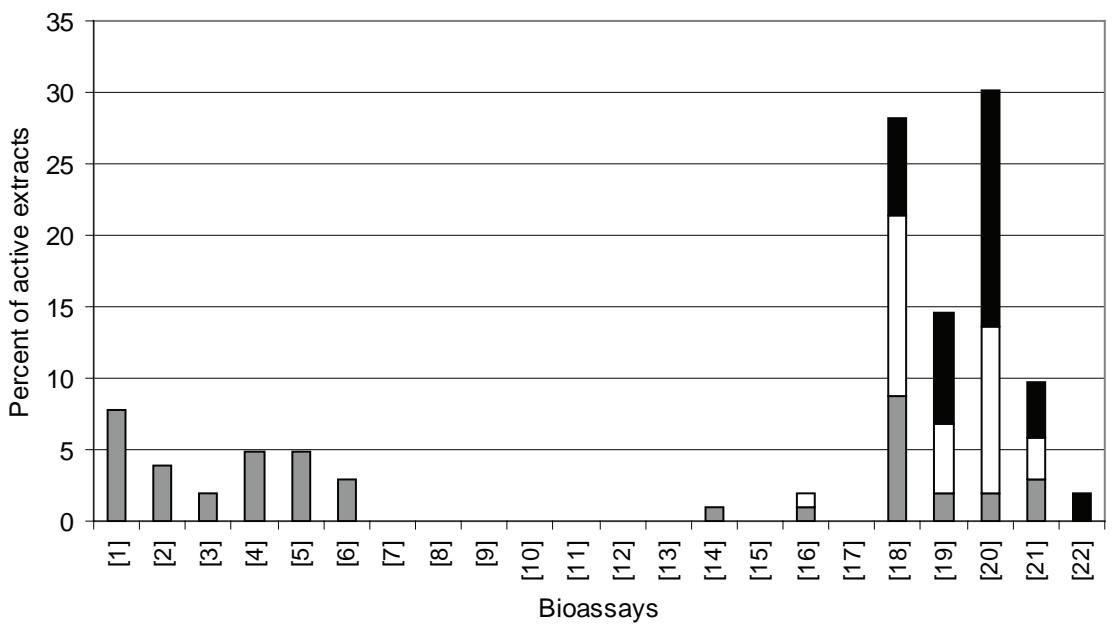

$\square$ low activity $\square$ moderate activity $\square$ high activity

For antimicrobial bioassays: [1] = Staphylococcus aureus ATCC 6538; [2] = Staphylococcus aureus (resistant strain \# 2.12a); [3] = Escherichia coli ATCC 25922; [4] = Pseudomonas aeruginosa (resistant strain \# 6.4); [5] = Enterobacter spp (resistant strain \# 1.17.b); [6] = Proteus spp (resistant strain \# 6.3); [7] = Candida albicans (ATCC 10231); [8] = Oxacilin resistant S. aureus (strain \# 11); [9] = Oxacilin resistant S. aureus (strain \# 18); [10] = Oxacilin resistant S. aureus (strain \# 35); [11] = Oxacilin resistant S. aureus (strain \# 36); [12] = Oxacilin resistant S. aureus (strain \# 61); [13] = Oxacilin resistant S. aureus (strain \# 63); [14] = Oxacilin resistant $S$. aureus (strain \# 68); [15] = Oxacilin resistant $S$. aureus (strain \# 108); [16] = Oxacilin resistant $S$. aureus (strain \# 115); [17] = Oxacilin resistant $S$. aureus (strain \# 135); antibacterial activity level: + inhibition hallii $>5 \mathrm{~mm}$ and $<10 \mathrm{~mm}$; ++ inhibition halii $>11 \mathrm{~mm}$ and < $14 \mathrm{~mm}$; +++ inhibition halii $>15 \mathrm{~mm}$; For antimycobacterial assay: [18] = Mycobacterium tuberculosis H37 Rv; antimycobacterial activity level: + MIC between 401 and $600 \mu \mathrm{g} / \mathrm{mL}$; ++ MIC between 201 and $400 \mu \mathrm{g} / \mathrm{mL}$; +++ MIC between 10 and $200 \mu \mathrm{g} /$ $\mathrm{mL}$; For cytotoxic bioassays: [19] = MCF-7 breast cancer cells; [20] = HCT-8 colon cancer cells; [21] = B16 murine melanoma cancer cells; cytotoxic activity level: + inhibition up to $50 \%$ of cancer cell growth; ++ inhibition between $50 \%$ and $75 \%$ of cancer cell growth; +++ inhibition larger than $75 \%$ of cell growth; For inhibition of Leishmania tarentolae adenosine phosphoribosyl transferase bioassay [22]: + inhibition of enzymatic activity between $40 \%$ and $60 \%$; ++ inhibition of enzymatic activity between $60 \%$ and $80 \%$; +++ inhibition of enzymatic activity higher than $80 \%$.

Figure 2. Percent of ascidian crude extracts active in each of the 22 bioassays. 


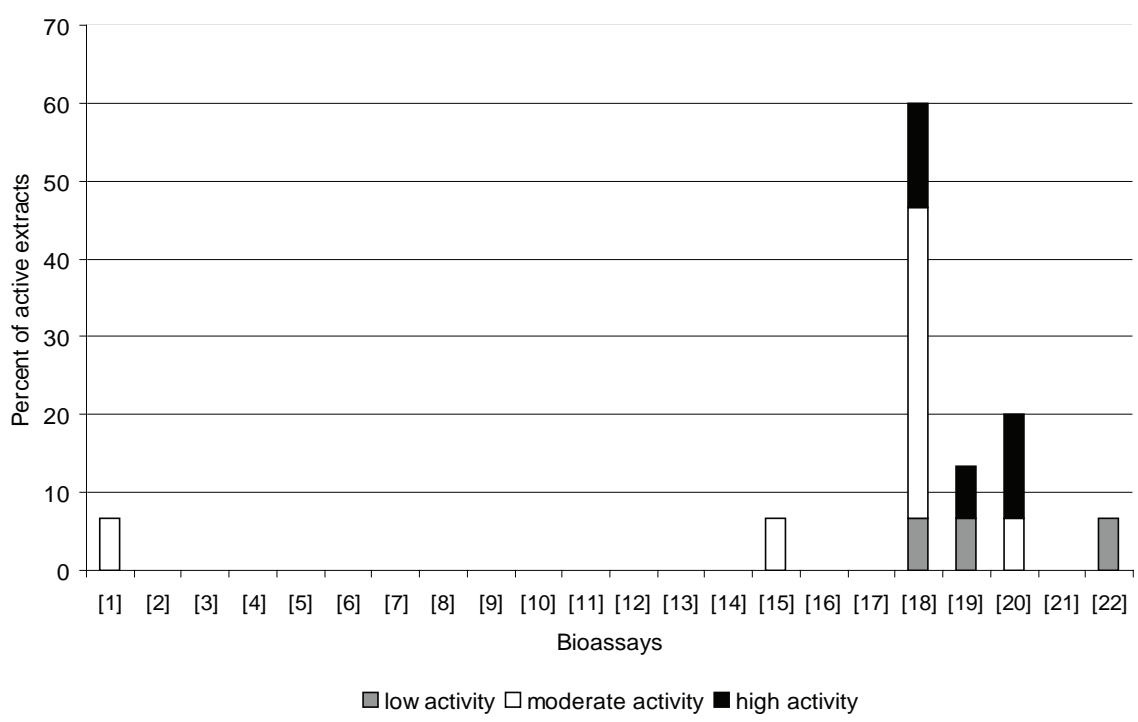

For antimicrobial bioassays: [1] = Staphylococcus aureus ATCC 6538; [2] = Staphylococcus aureus (resistant strain \# 2.12a); [3] = Escherichia coli ATCC 25922; [4] = Pseudomonas aeruginosa (resistant strain \# 6.4); [5] = Enterobacter spp (resistant strain \# 1.17.b); [6] = Proteus spp (resistant strain \# 6.3); [7] = Candida albicans (ATCC 10231); [8] = Oxacilin resistant $S$. aureus (strain \# 11); [9] = Oxacilin resistant $S$. aureus (strain \# 18); [10] = Oxacilin resistant $S$. aureus (strain \# 35); [11] = Oxacilin resistant $S$. aureus (strain \# 36); [12] = Oxacilin resistant $S$. aureus (strain \# 61); [13] = Oxacilin resistant S. aureus (strain \# 63); [14] = Oxacilin resistant $S$. aureus (strain \# 68); [15] = Oxacilin resistant S. aureus (strain \# 108); [16] = Oxacilin resistant S. aureus (strain \# 115); [17] = Oxacilin resistant S. aureus (strain \# 135); antibacterial activity level: + inhibition hallii $>5 \mathrm{~mm}$ and $<10 \mathrm{~mm}$; ++ inhibition halii $>11 \mathrm{~mm}$ and $<14 \mathrm{~mm}$; +++ inhibition halii > $15 \mathrm{~mm}$; For antimycobacterial assay: [18] = Mycobacterium tuberculosis H37 Rv; antimycobacterial activity level: + MIC between 401 and $600 \mu \mathrm{g} / \mathrm{mL}$; ++ MIC between 201 and $400 \mu \mathrm{g} / \mathrm{mL}$; +++ MIC between 10 and $200 \mu \mathrm{g} / \mathrm{mL}$; For cytotoxic bioassays: [19] = MCF-7 breast cancer cells; [20] = HCT-8 colon cancer cells; [21] = B16 murine melanoma cancer cells; cytotoxic activity level: + inhibition up to $50 \%$ of cancer cell growth; ++ inhibition between $50 \%$ and $75 \%$ of cancer cell growth; +++ inhibition larger than $75 \%$ of cell growth; For inhibition of Leishmania tarentolae adenosine phosphoribosyl transferase bioassay [22]: + inhibition of enzymatic activity between $40 \%$ and $60 \%$; ++ inhibition of enzymatic activity between $60 \%$ and $80 \%$; +++ inhibition of enzymatic activity higher than $80 \%$.

Figure 3. Percent of bryozoan crude extracts active in each of the 22 bioassays. 


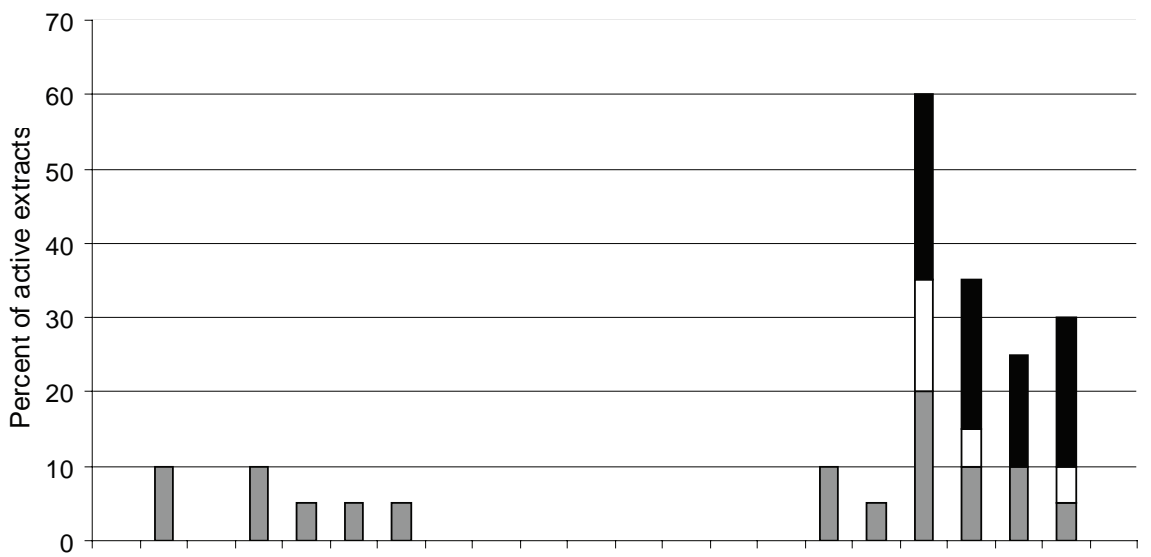

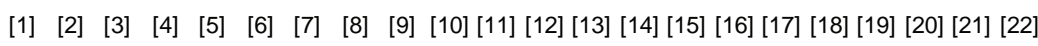

Bioassays

$\square$ low activity $\square$ moderate activity $\square$ high activity

For antimicrobial bioassays: [1] = Staphylococcus aureus ATCC 6538; [2] = Staphylococcus aureus (resistant strain \# 2.12a); [3] = Escherichia coli ATCC 25922; [4] = Pseudomonas aeruginosa (resistant strain \# 6.4); [5] = Enterobacter spp (resistant strain \# 1.17.b); [6] = Proteus spp (resistant strain \# 6.3); [7] = Candida albicans (ATCC 10231); [8] = Oxacilin resistant $S$. aureus (strain \# 11); [9] = Oxacilin resistant S. aureus (strain \# 18); [10] = Oxacilin resistant $S$. aureus (strain \# 35); [11] = Oxacilin resistant S. aureus (strain \# 36); [12] = Oxacilin resistant $S$. aureus (strain \# 61); [13] = Oxacilin resistant $S$. aureus (strain \# 63); [14] = Oxacilin resistant $S$. aureus (strain \# 68); [15] = Oxacilin resistant S. aureus (strain \# 108); [16] = Oxacilin resistant S. aureus (strain \# 115); [17] = Oxacilin resistant $S$. aureus (strain \# 135); antibacterial activity level: + inhibition hallii $>5 \mathrm{~mm}$ and $<10 \mathrm{~mm}$; ++ inhibition halii $>11 \mathrm{~mm}$ and $<14 \mathrm{~mm}$; +++ inhibition halii $>15 \mathrm{~mm}$; For antimycobacterial assay: [18] = Mycobacterium tuberculosis H37 Rv; antimycobacterial activity level: + MIC between 401 and $600 \mu \mathrm{g} / \mathrm{mL}$; ++ MIC between 201 and $400 \mu \mathrm{g} / \mathrm{mL}$; +++ MIC between 10 and $200 \mu \mathrm{g} / \mathrm{mL}$; For cytotoxic bioassays: [19] = MCF-7 breast cancer cells; [20] = HCT-8 colon cancer cells; [21] = B16 murine melanoma cancer cells; cytotoxic activity level: + inhibition up to $50 \%$ of cancer cell growth; ++ inhibition between $50 \%$ and $75 \%$ of cancer cell growth; +++ inhibition larger than $75 \%$ of cell growth; For inhibition of Leishmania tarentolae adenosine phosphoribosyl transferase bioassay [22]: + inhibition of enzymatic activity between $40 \%$ and $60 \%$; ++ inhibition of enzymatic activity between $60 \%$ and $80 \%$; +++ inhibition of enzymatic activity higher than $80 \%$.

Figure 4. Percent of octocorals crude extracts active in each of the 22 bioassays.

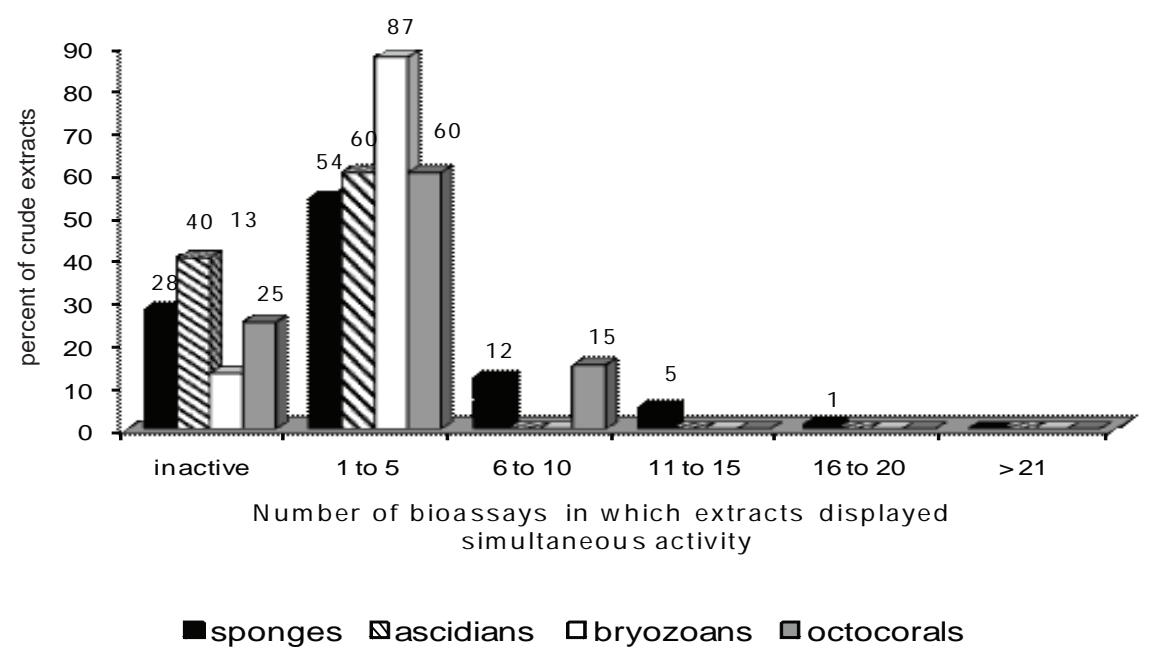

Figure 5. Bioactivity profile of marine sponge, ascidians, bryozoans and octocorals crude extracts in the 22 bioassays. 


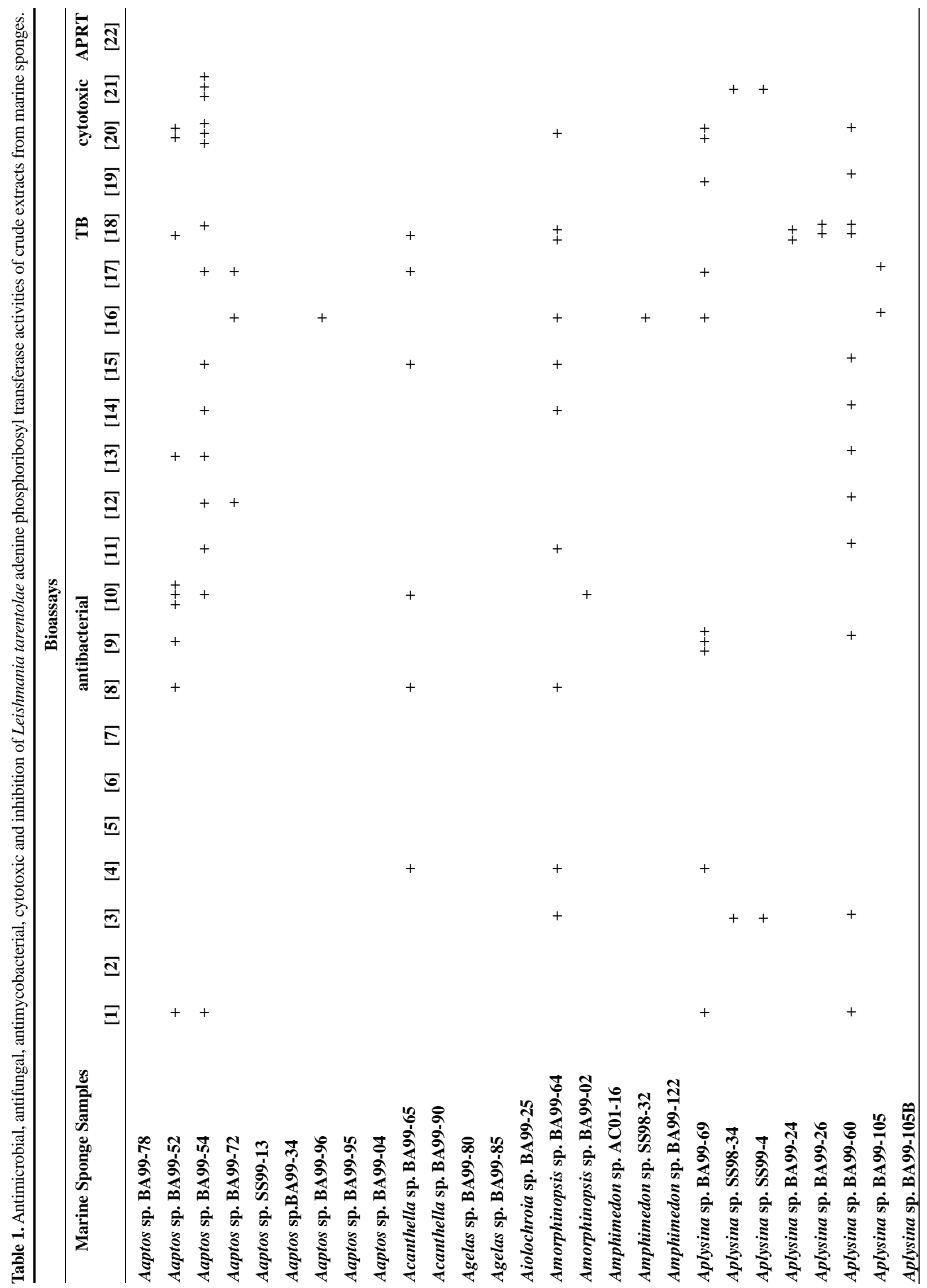




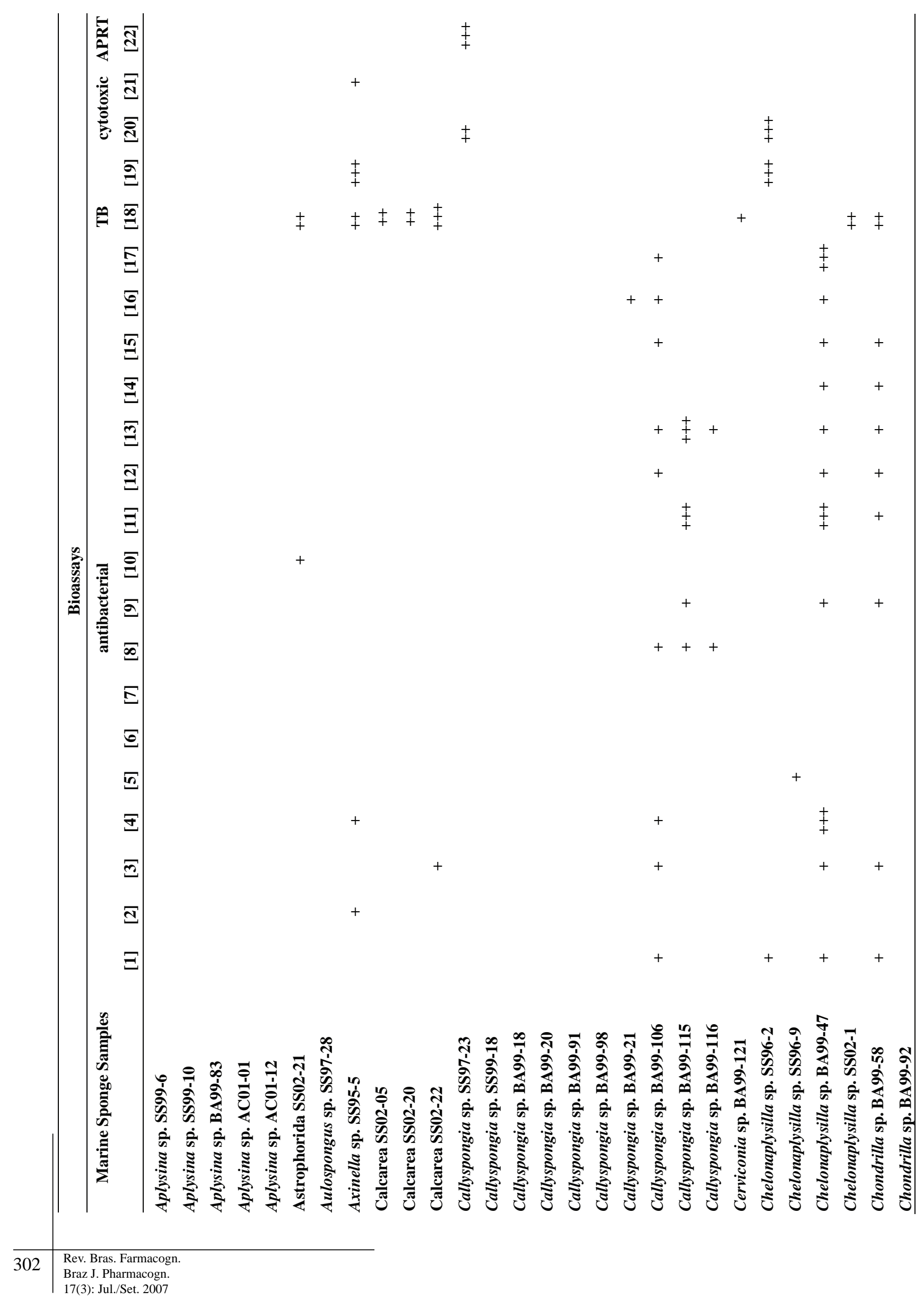




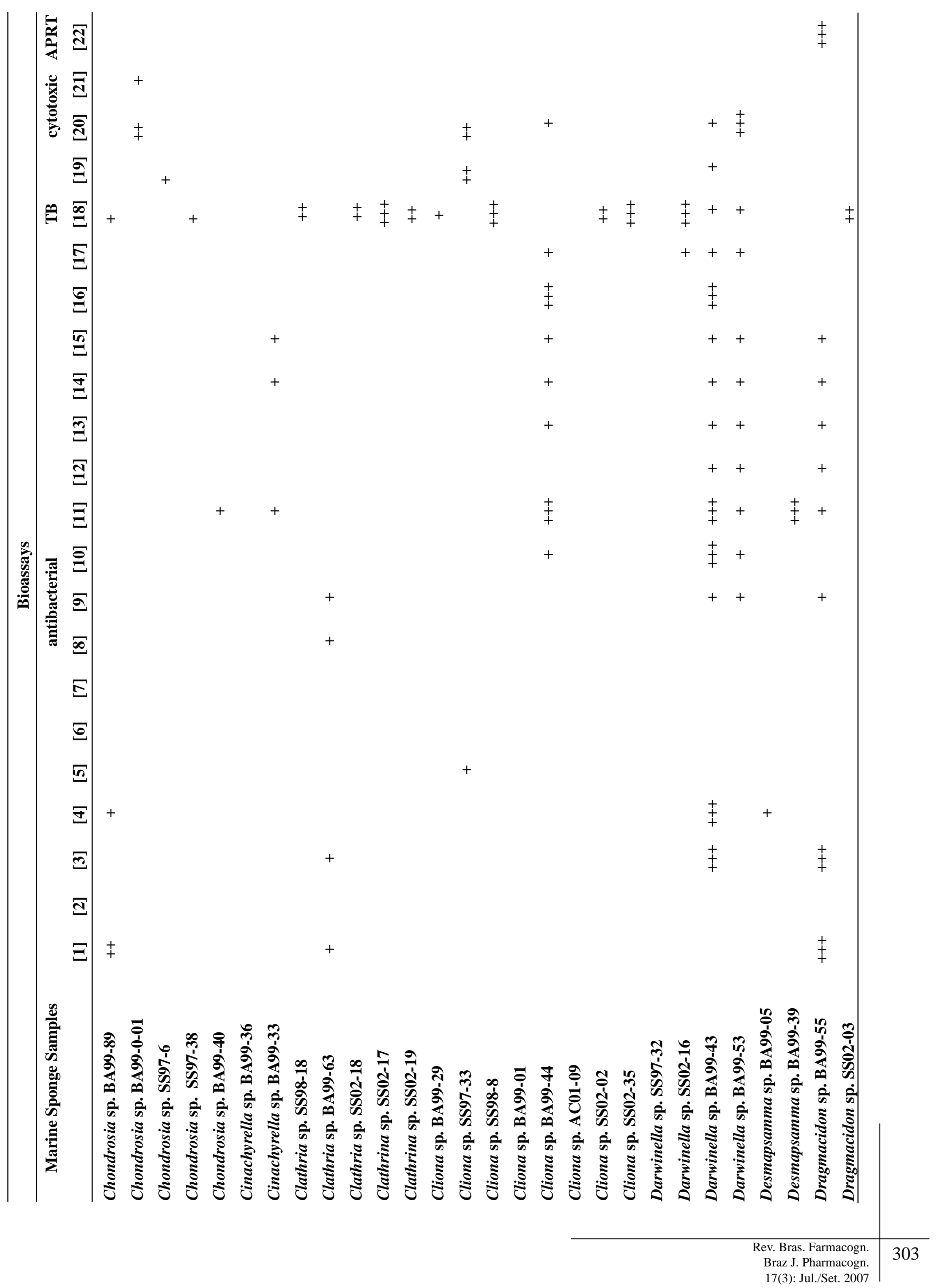




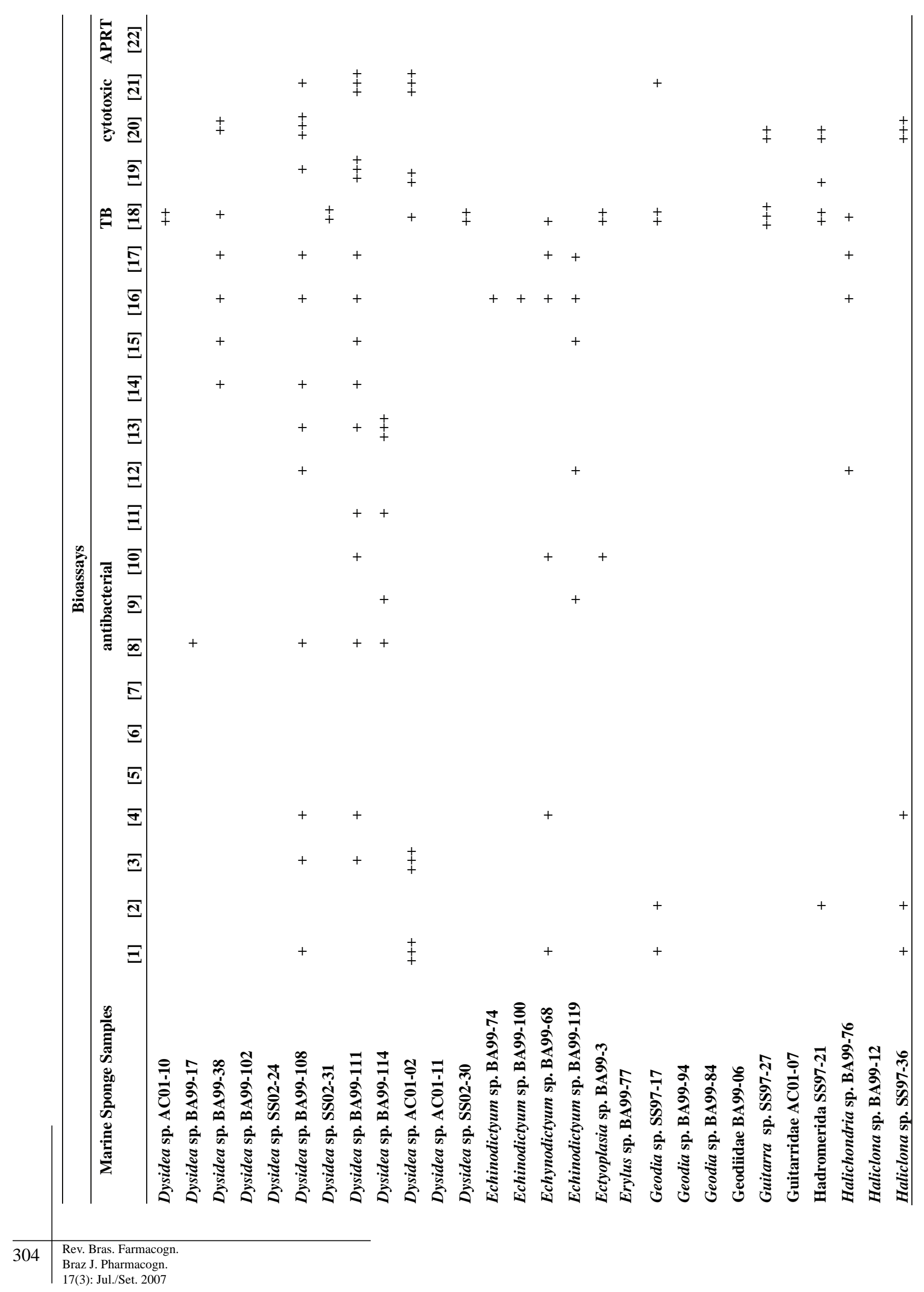




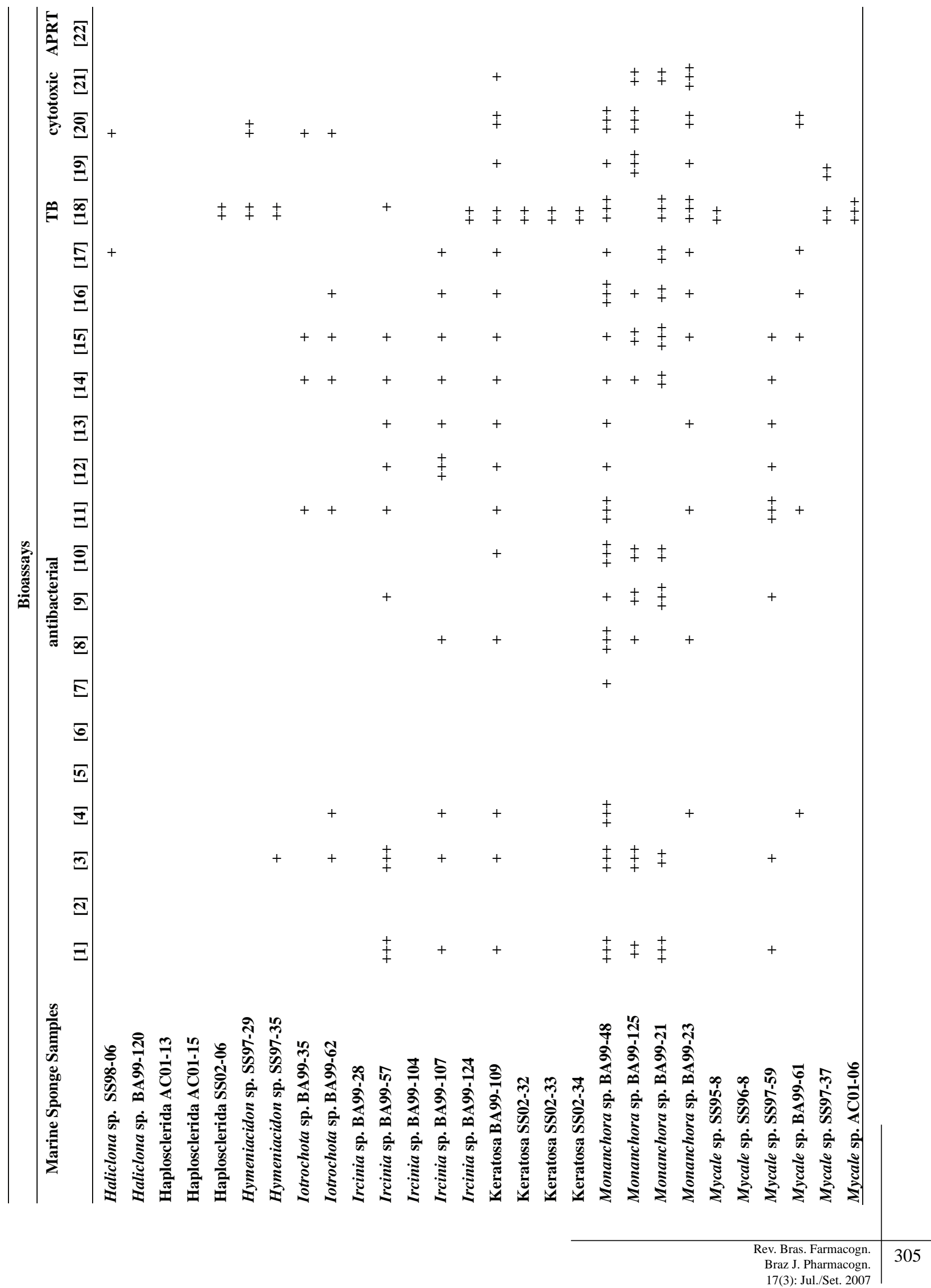




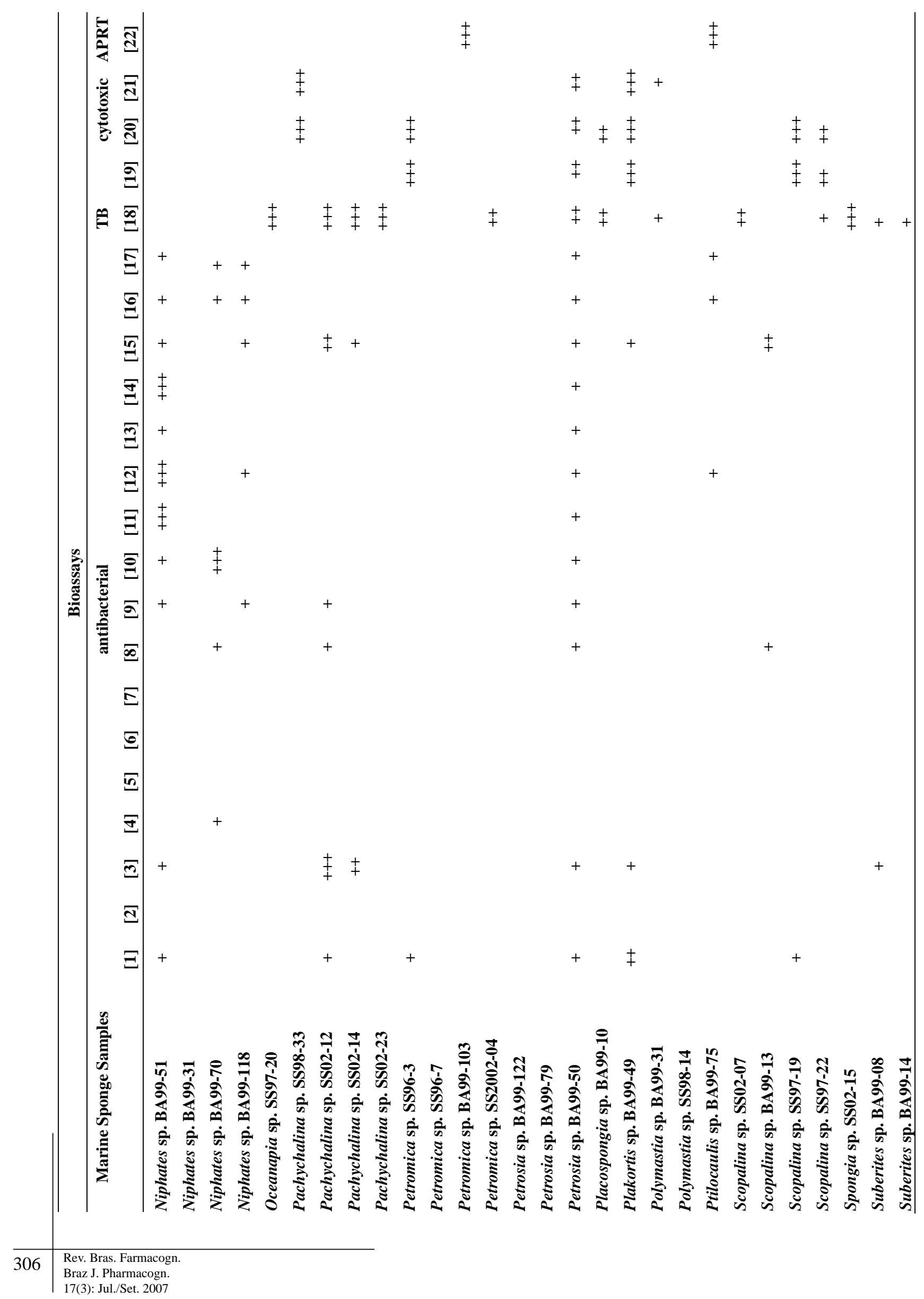




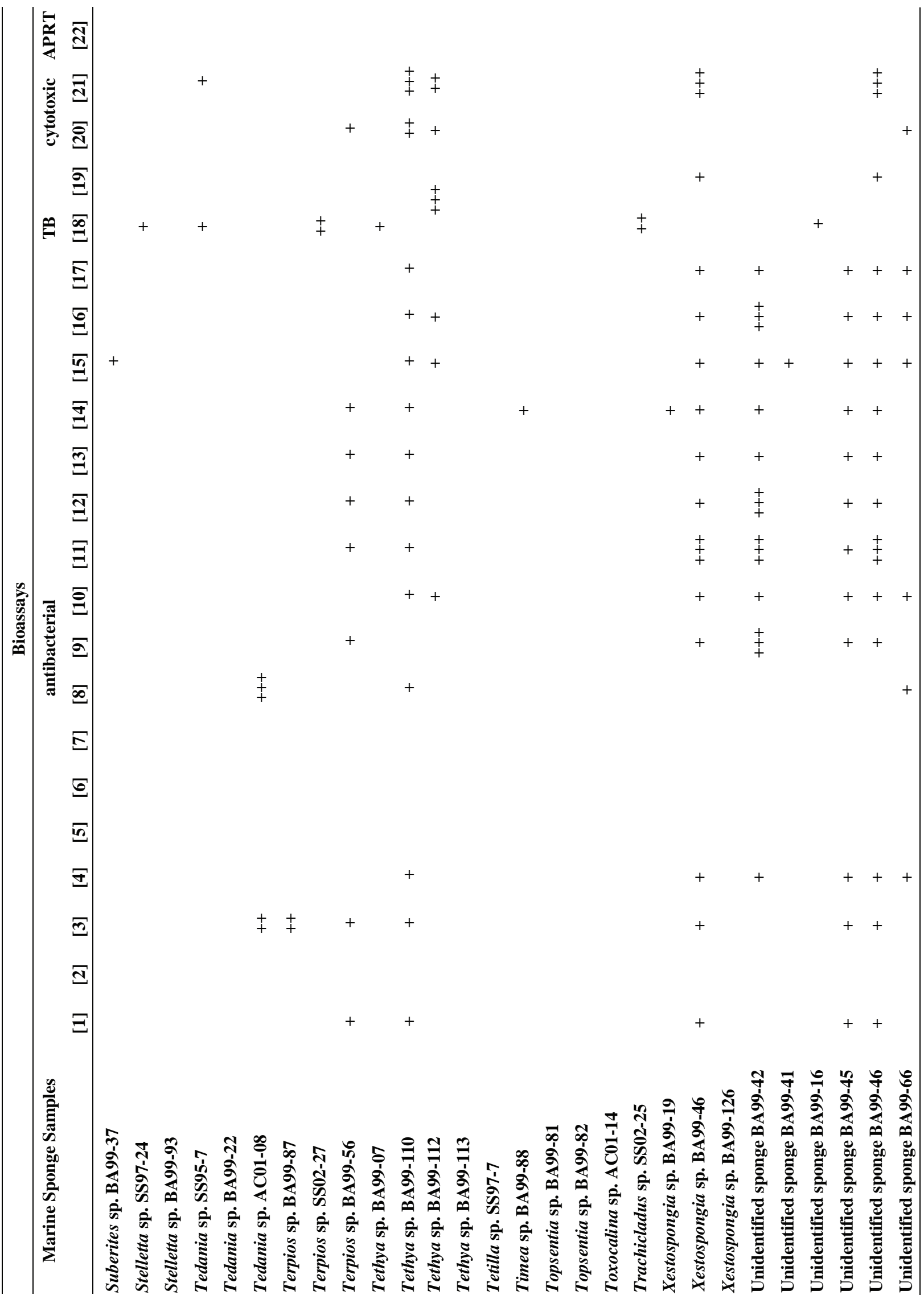




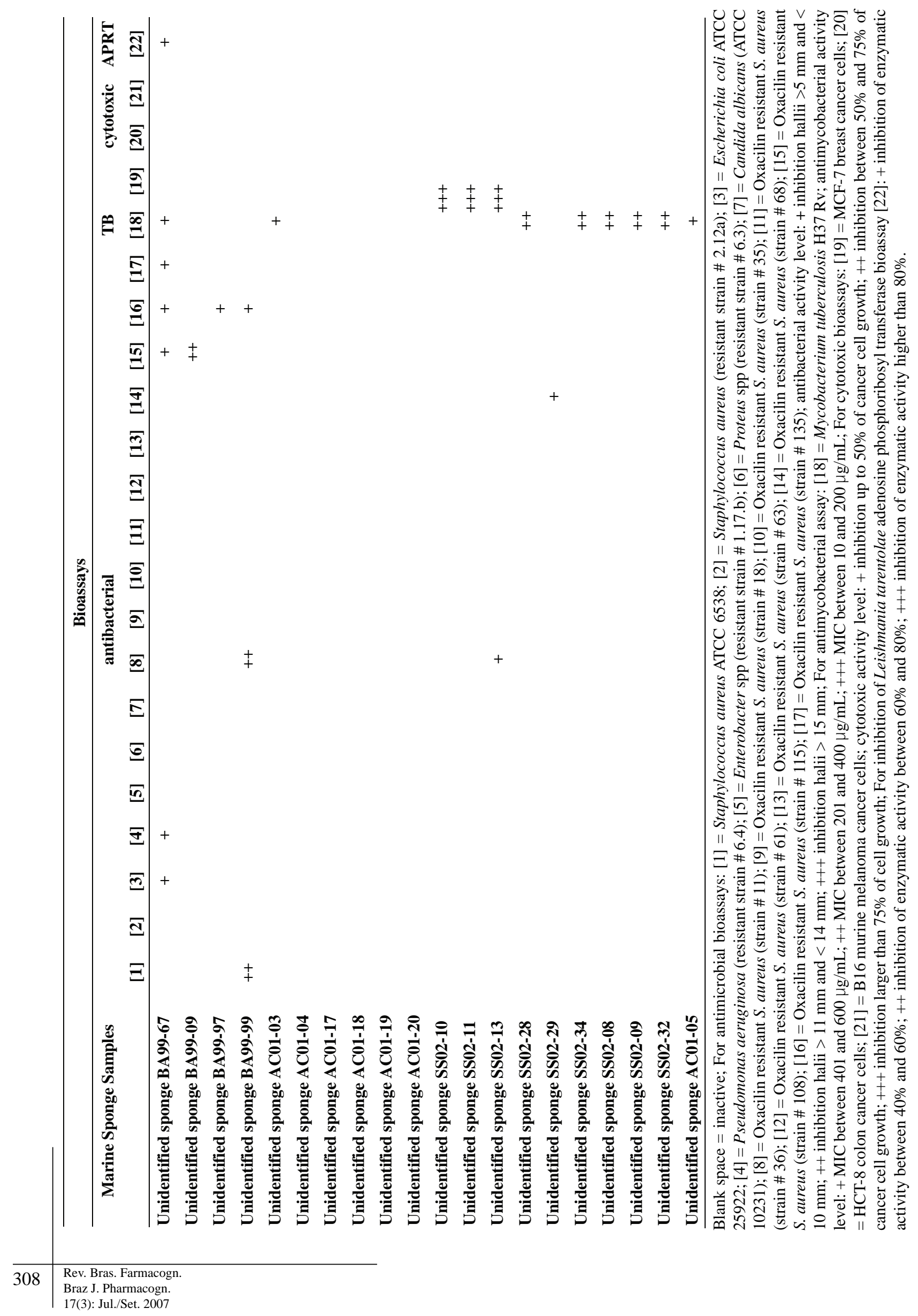




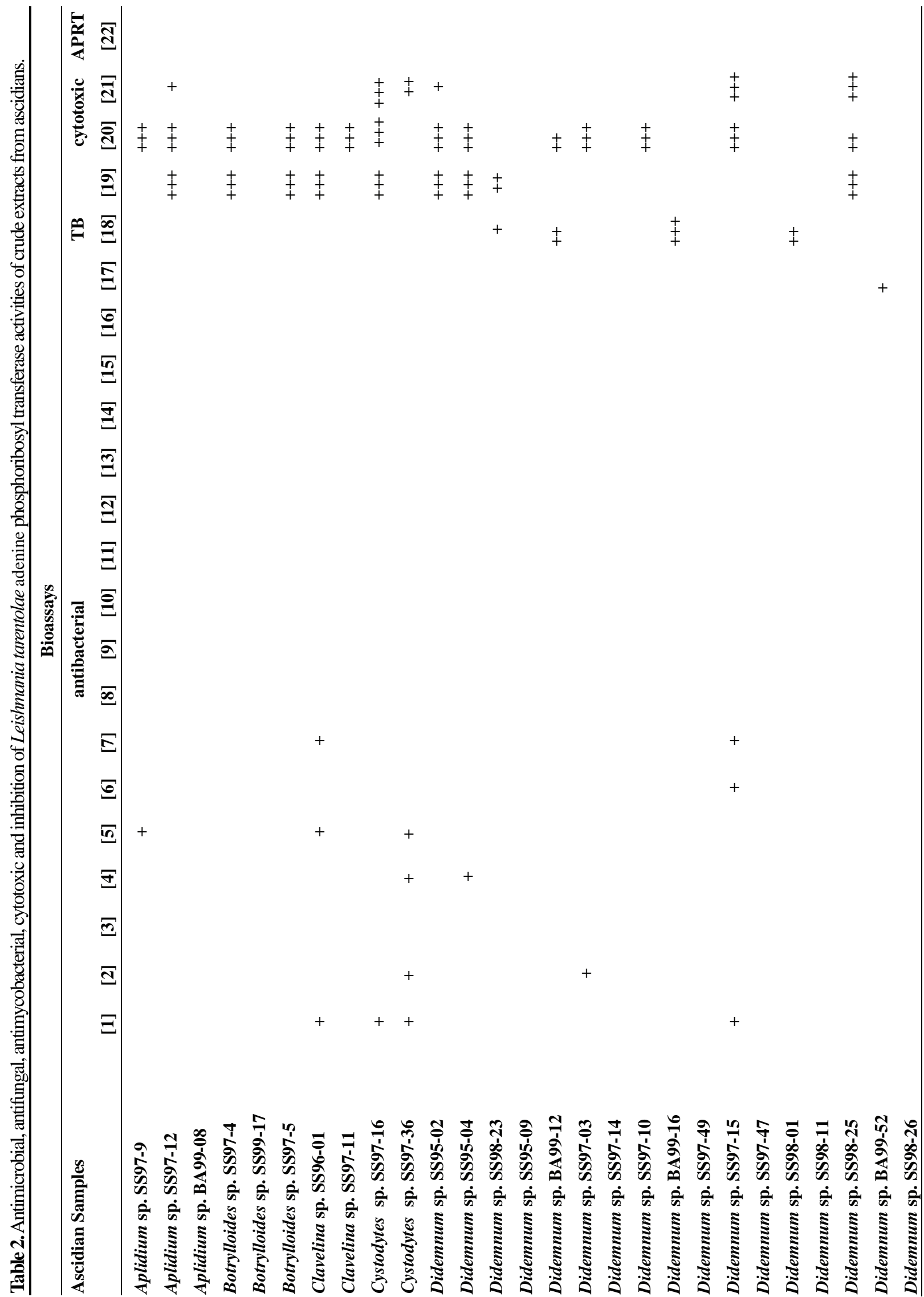




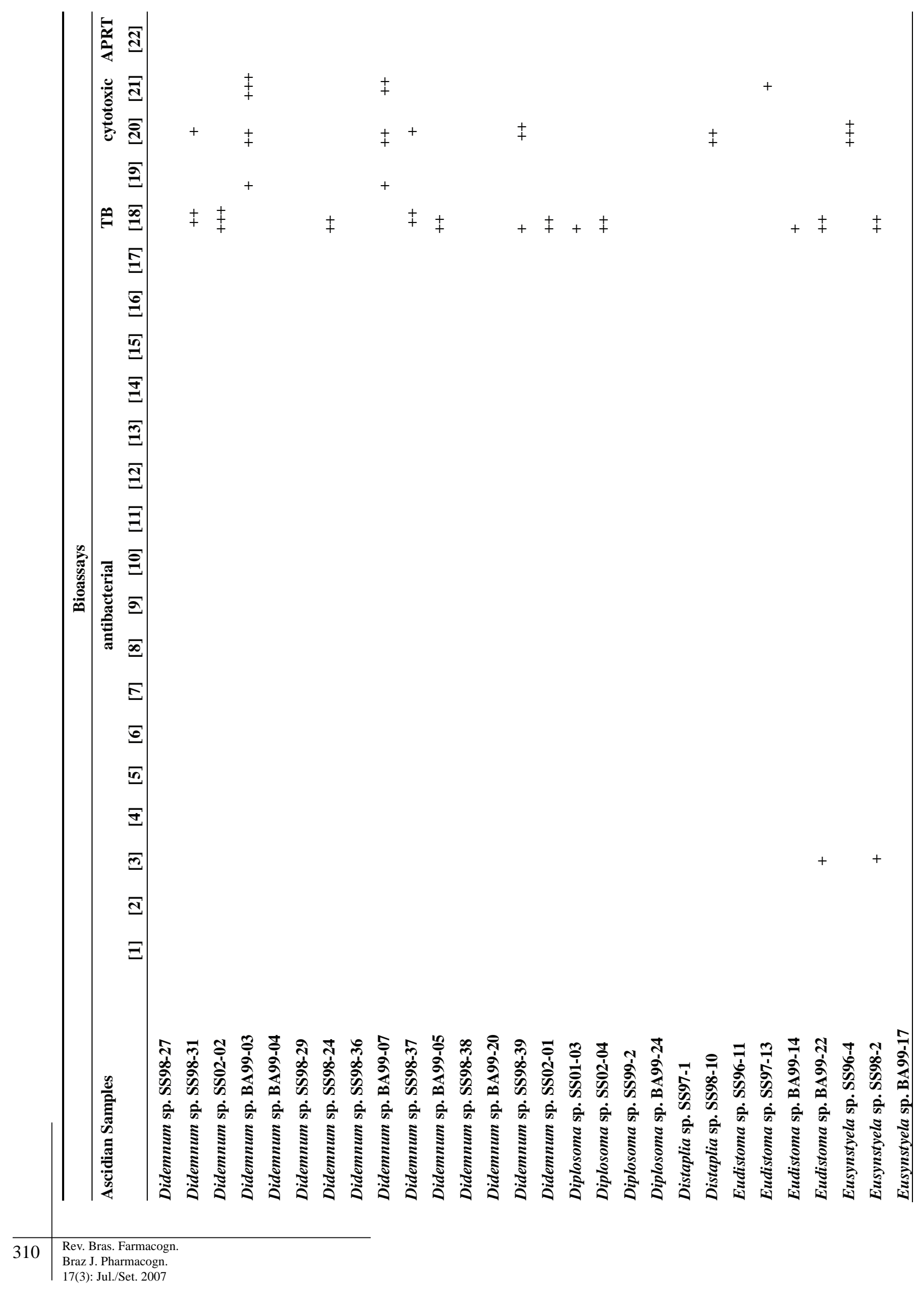




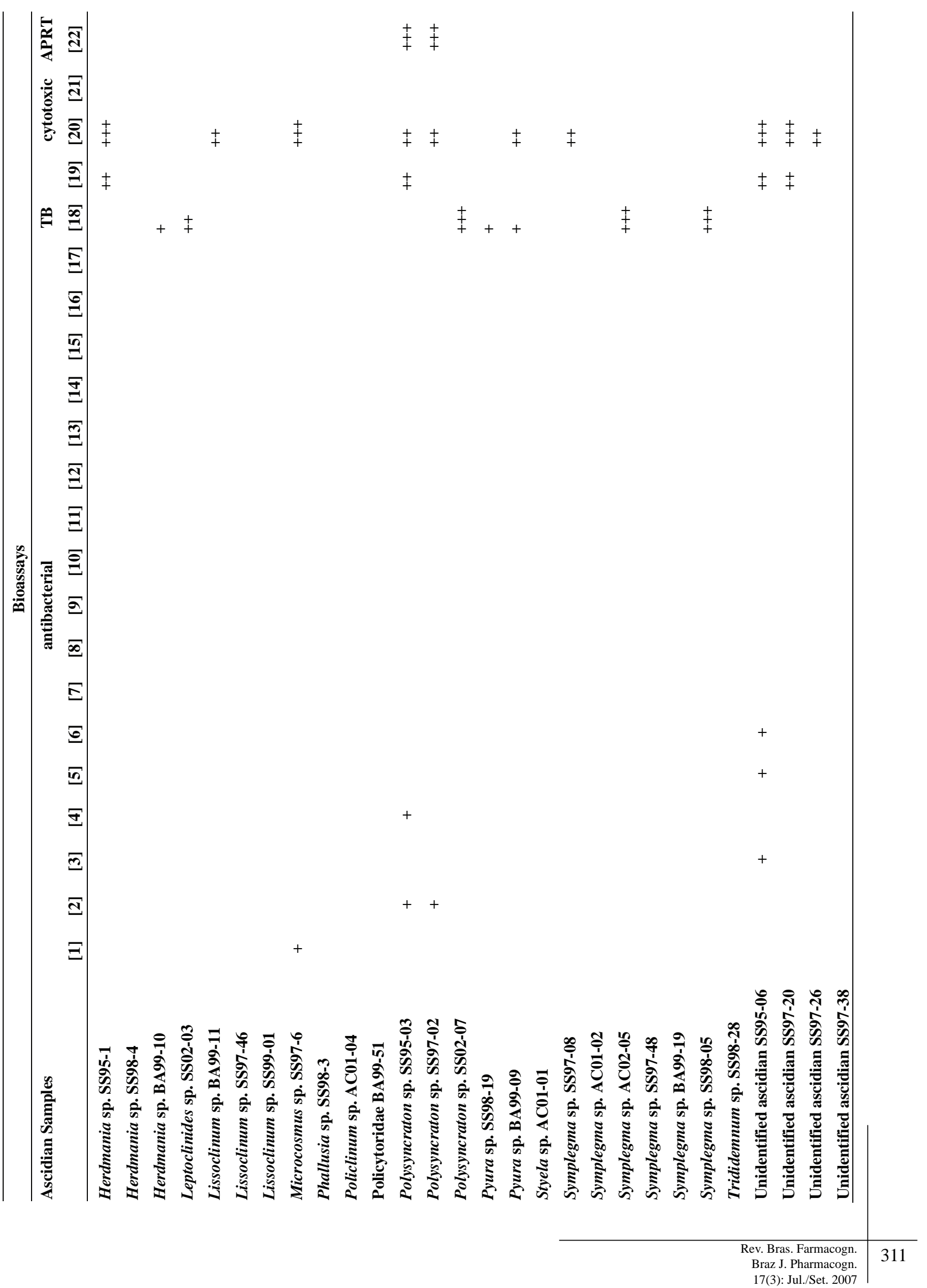




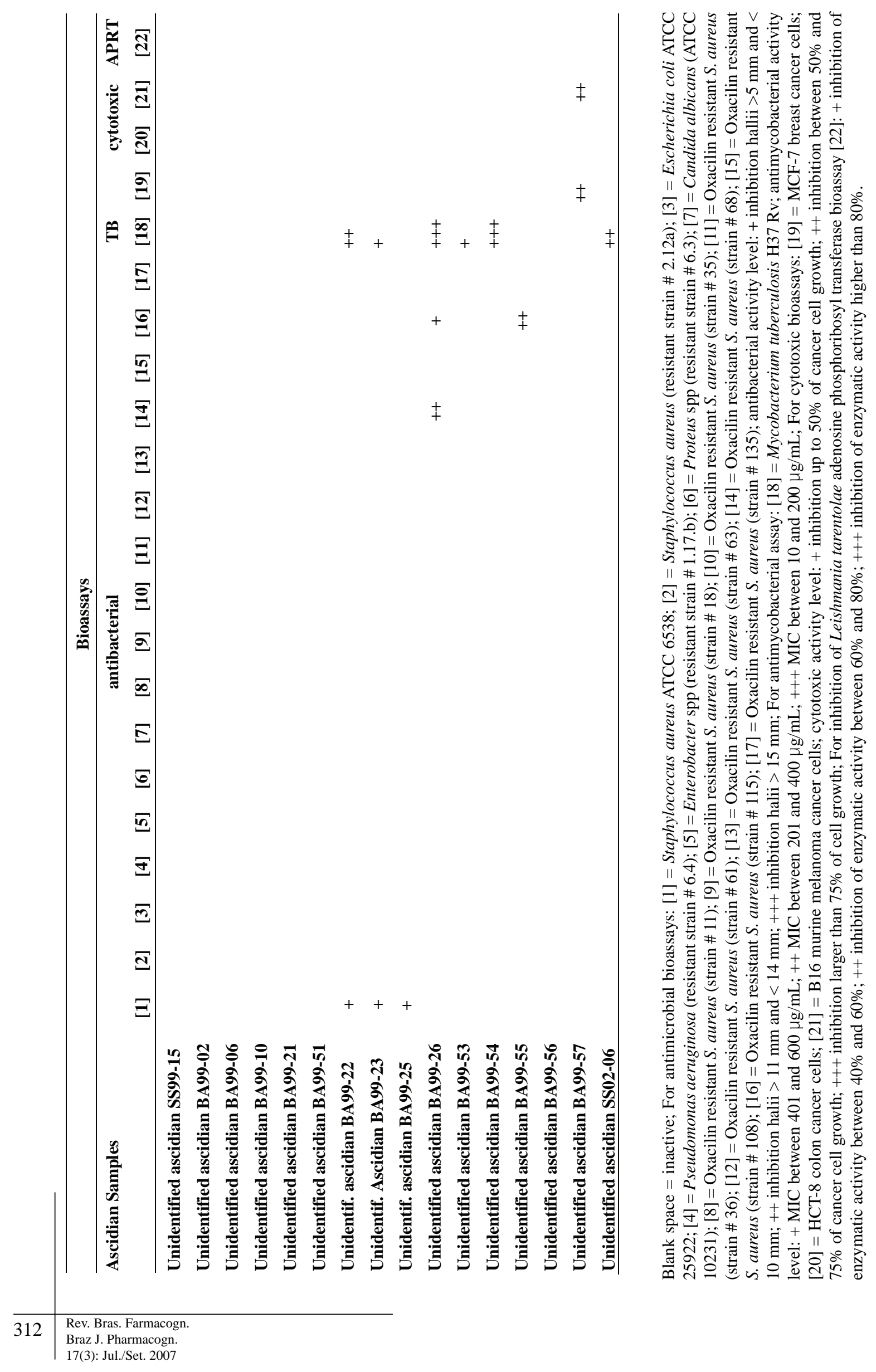




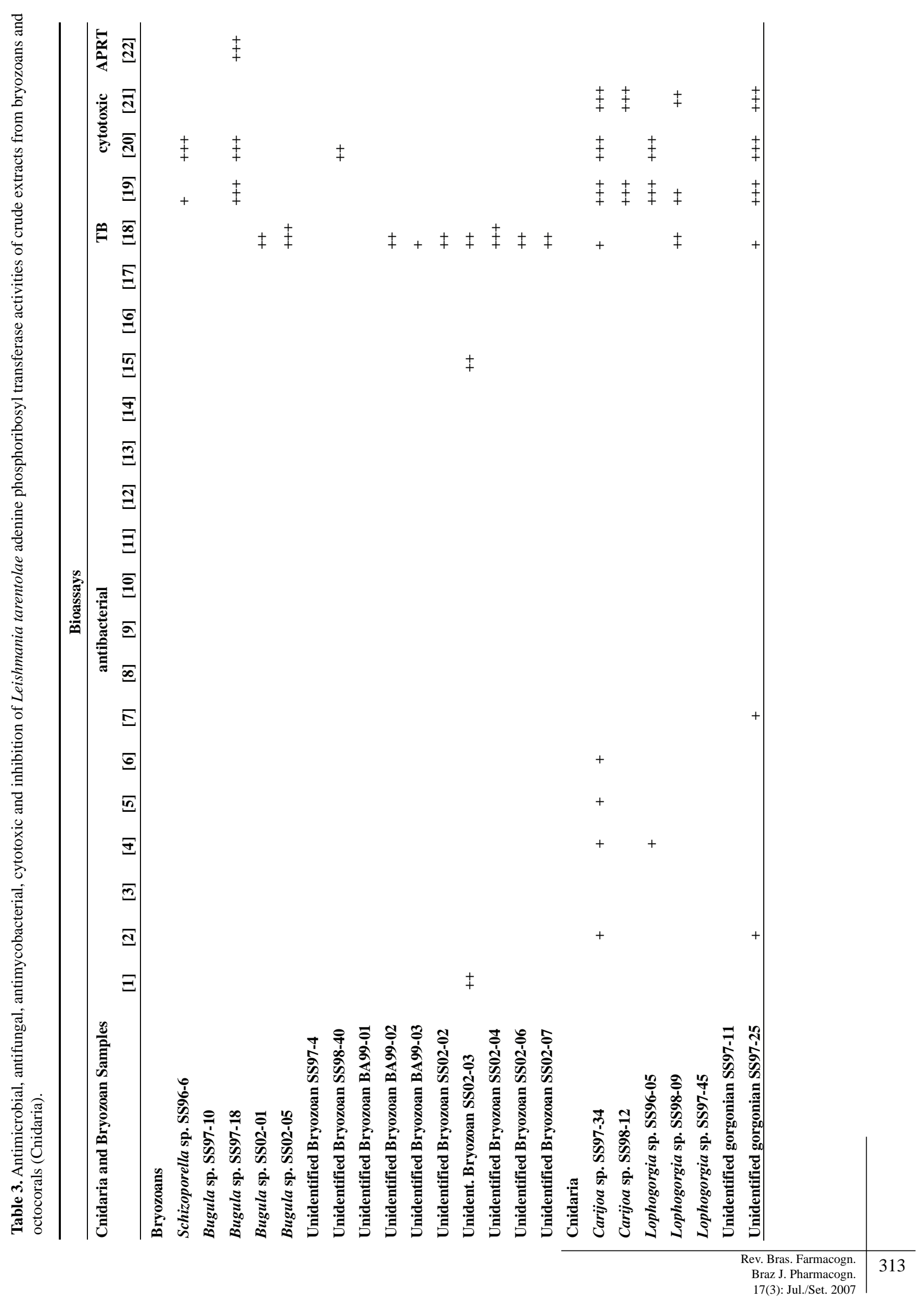




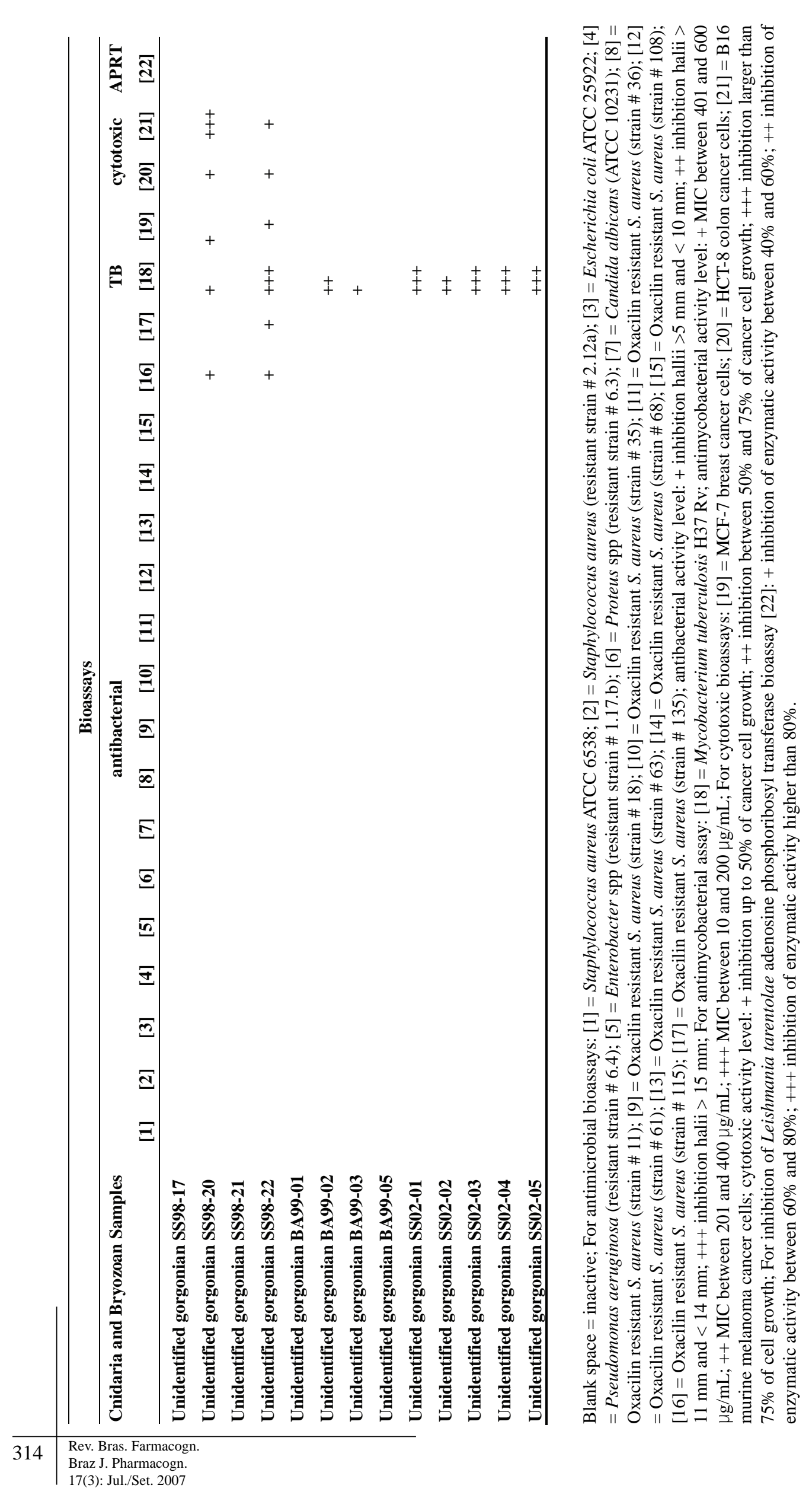


Berlinck RGS, Kossuga MH 2005. Natural guanidine derivatives. Nat Prod Rep 22: 516-550.

Berlinck RGS 2007. Polycyclic diamine alkaloids of marine sponges. Top Heterocycl Chem, in press.

Berlinck RGS, Kossuga MH 2007. Guanidine alkaloids from marine invertebrates. In: Fattorusso E, TaglialatelaScafati O (Eds) Modern Alkaloids. Berlin, Germany: Springer.

Berlinck RGS, Braekman JC, Daloze D, Hallenga K, Ottinger R, Bruno I, Riccio R 1990. New guanidine alkaloids from the Mediterranean sponge Crambe crambe. Tetrahedron Lett 31: 6531-6534.

Berlinck RGS, Braekman JC, Daloze D, Bruno I, Riccio R, Rogeau D, Amade P 1992. Crambine-C1 and crambine-C2 - 2 further ichthyotoxic guanidine alkaloids from the sponge Crambe crambe. $J$ Nat Prod 55: 528-532.

Berlinck RGS, Braekman JC, Daloze D, Bruno I, Riccio R. Ferri S, Spampinato S, Speroni E 1993. Polycyclic guanidine alkaloids from the marine sponge Crambe crambe and $\mathrm{Ca}^{2+}$ Channel blocker activity of crambescin-816. J Nat Prod 56: 1007-1015.

Berlinck RGS, Britton R, Piers E, Lim L, Roberge M, Rocha RM, Andersen RJ 1998. Granulatimide and isogranulatimide, aromatic alkaloids with G2 checkpoint inhibition activity isolated from the Brazilian ascidian Didemnum granulatum: structure elucidation and synthesis. J Org Chem 63: 98509856.

Berlinck RGS, Hajdu E, Rocha RM, de Oliveira JHHL, Hernández ILC, Seleghim MHR, Granato AC, Almeida EVR, Nuñez CV, Muricy G, Peixinho S, Pessoa C, Moraes MO, Cavalcanti BC, Nascimento GGF, Thiemann O, Silva M, Souza AO, Silva CL, Minarini PRR 2004. Challenges and rewards of research in marine natural products Chemistry in Brazil. J Nat Prod 67: 510-522.

Bhosale SH, Nagle VL, Jagtap TG 2002. Antifouling potential of some marine organisms from India against species of Bacillus and Pseudomonas. Mar Biotechnol 4: 111-118.

Blunden G 2001. Biologically active compounds from marine organisms. Phytother Res 15: 89-94.

Blunt JW, Copp BR, Hu WP, Munro MHG, Northcote PT, Prinsep MR 2007. Marine Natural Products, Nat Prod Rep 24: 31-86.

Burns E, Ifrach I, Carmeli S, Pawlik JR, Ilan M 2003. Comparison of anti-predatory defenses of Red Sea and Caribbean sponges. I. Chemical defense. Mar Ecol Prog Ser 252: 105-114.

Chanas B, Pawlik JR, Lindel T, Fenical W 1996. Chemical defense of the Caribbean sponge Agelas clathrodes (Schmidt). J Exp Mar Biol Ecol 208: 185-196.

Collins LA, Franzblau SG 1997. Microplate Alamar Blue assay versus BACTEC 460 system for high-throughput screening of compounds against Mycobacterium tuberculosis and Mycobacterium avium. Antimicrob Agents Chemother 41: 1004-1009.

Copp BR 2003. Antimycobacterial natural products. Nat Prod Rep 20: 535-557.

Coutinho AF, Chanas B, Souza TML, Frugrulhetti ICPP, Epifanio RA 2002. Anti HSV-1 alkaloids from a feeding deterrent marine sponge of the genus Aaptos.
Heterocycles 57: 1265-1272.

Cragg GM, Newman DJ 1999. Discovery and development of antineoplastic agents from natural sources. Cancer Invest 17: 153-163.

Cragg GM, Newman DJ 2001. Natural product drug discovery in the next millennium. Pharm Biol 39: 8-17.

Davidson BS 1993. Ascidians: producers of amino-acid derived metabolites. Chem Rev 93: 1771-1791.

Davis AR, Targett NM, McConnell OJ, Young CM 1989. Epibiosis of marine algae and benthic invertebrates: natural products chemistry and other mechanisms inhibiting settlement and overgrowth, In: Scheuer PJ (Ed.) Bioorganic Marine Chemistry. Berlin, Springer-Verlag, Vol. 3, p. 85-114.

De Vries DJ, Beart PM 1995. Fishing for drugs from the sea: status and strategies. Trends Pharm Sci 16: 275-279.

Dionisio-Sese ML, Ishikura M, Maruyama T, Miyachi S 1997. UV-absorbing substances in the tunic of a colonial ascidian protect its symbiont, Prochloron, from damage by UV-B radiation. Mar Biol 128: 455-461.

Donia M, Hamann MT 2003. Marine natural products and their potential applications as anti-infective agents. Lancet Infect Dis 3: 338-348.

Dresch RR, Haeser AS, Lerner C, Mothes B, Vozári-Hampe MM, Henriques AT 2005. Detecção de atividade lectínica e atividade hemolítica em extratos de esponjas (Porifera) nativas da costa atlântica do Brasil. Rev Bras Farmacogn 15: 16-22.

Dunlap WC, Chalker BE, Oliver JK 1986. Bathymetric adaptations of reef-building corals at Davies Reef, Great Barrier Reef, Australia. III UV-B absorbing compounds. J Exp Mar Biol Ecol 104: 239-248.

El Sayed KA, Bartyzel P, Shen XY, Perry TL, Kjawiony JK, Hamann MT 2000. Marine natural products as antituberculosis agents. Tetrahedron 56: 949-953.

Ely R, Supriya T, Naik CG 2004. Antimicrobial activity of marine organisms collected off the coast of South East India. J Exp Mar Biol Ecol 309: 121-127.

Encarnación DR, Franzblau SG, Tapia CA, Cedillo-Rivera $\mathrm{R}$ 2000. Screening of marine organisms for antimicrobial and antiprotozoal activity. Pharm Biol 38: 379-384.

Epifanio RD, Gabriel R, Martins DL, Muricy G 1999a. The sesterterpene variabilin as a fish-predation deterrent in the Western Atlantic sponge Ircinia strobilina. $J$ Chem Ecol 25: 2247-2254.

Epifanio RD, Martins DL, Villaça R, Gabriel R 1999b. Chemical defenses against fish predation in three Brazilian octocorals: 11,12 -epoxypukalide as a feeding deterrent in Phyllogorgia dilatata. $\mathrm{J}$ Chem Ecol 25: 2255-2265.

Faulkner DJ 2000a. Highlights of marine natural products chemistry (1972-1999). Nat Prod Rep 17: 1-6.

Faulkner DJ 2000b. Marine Pharmacology. Ant van Leeuw 77: 135-145.

Faulkner DJ, Newman DJ, Cragg GM 2004. Investigations of the marine flora and fauna of the Islands of Palau. Nat Prod Rep 21: 50-76.

Fenical W, Okuda RK, Bandurraga MM, Culver P, Jacobs RS 1981. Lophotoxin: a novel neuromuscular toxin from Pacific sea whips of the genus Lophogorgia. Science 212: 1512-1514.

Fusetani N 1997. Marine natural products influencing 
larval settlement and metamorphosis of benthic invertebrates. Curr Org Chem 1: 127-152.

Galera J, Turon X, Uriz MJ, Becerro MA 2000. Microstructure variation in sponges sharing growth form: the encrusting demosponges Dysidea avara and Crambe crambe. Acta Zool 81: 93-107.

Garson MJ 1994. The biosynthesis of sponge secondary metabolites: why it is important, In: By R. W. M van Soest RWM, Van Kempen TMG, Braekman JC (Eds.) Sponges in Time and Space. Rotterdam, Balkema, pp. 427-440.

Grabley S, Thiericke R 1999. Drug Discovery from Nature. Berlin: Springer.

Granato AC, Berlinck RGS, Schefer AB, Magalhães A, Ferreira AG, de Sanctis B, Freitas JC, Migotto, AE, Hajdu E 2000. Produtos naturais das esponjas marinhas Aaptos sp., Hymeniacidon aff. heliophila, e do nudibrânquio Doris aff. verrucosa. Quim Nova 23: 594-599.

Gray CA, de Lira SP, Silva M, Pimenta EF, Thiemann OH, Oliva G, Hajdu E, Andersen RJ, Berlinck RGS 2006. Sulfated meroterpenoids from the Brazilian sponge Callyspongia sp. are inhibitors of the antileishmaniasis target adenosine phosphoribosyl transferase. J Org Chem 71: 8685-8690.

Haefner B 2003. Drugs from the deep: marine natural products as drug candidates. Drug Disc Today 8: 536-543.

Hale KJ, Hummersone MG, Manaviazar S, Frigerio M 2002. The chemistry and biology of the bryostatin antitumour macrolides. Nat Prod Rep 19: 413-453.

Hattori T, Matsuo S, Adachi K, Shizuri Y 2001. Isolation of antifouling substances from the Palauan sponge Protophlitaspongia aga. Fish Sci 67: 690-693.

Henrikson AA, Pawlik JR 1995. A new antifouling method: results from field experiments using extracts of four marine organisms. J Exp Mar Biol Ecol 194: 157165.

Jack D 1998. Combing the oceans for new therapeutic agents. The Lancet 352: 794.

Jares-Erijman EA, Ingrum AL, Carney JR, Rinehart KL, Sakai R 1993a. Polycyclic guanidine-containing compounds from the Mediterranean sponge Crambe crambe - the structure of 13,14,15-isocrambescidin 800 and the absolute stereochemistry of the pentacyclic guanidine moieties of the crambescidins. J Org Chem 58: 4805-4808.

Jares-Erijman EA, Ingrum EA, Sun FR, Rinehart KL 1993b. On the structures of crambescin-B and crambescinC1. J Nat Prod 56: 2186-2188.

Jares-Erijman EA, Sakai R, Rinehart KL 1991. Crambescidins - new antiviral and cytotoxic compounds from the sponge Crambe crambe. J Org Chem 56: 57125715.

Jimenez PC, Fortier SC, Lotufo TMC, Pessoa C, Moraes MEA, Moraes MO, Costa-Lotufo LV 2003. Biological activity in extracts of ascidians (Tunicata, Ascidiacea) from the northeastern Brazilian coast. $J$ Exp Mar Biol Ecol 287: 93-101.

Kelly SR, Jensen PR, Henkel TP, Fenical W, Pawlik JR 2003. Effects of Caribbean sponge extracts on bacterial attachment. Aquat Microb Ecol 31: 175-182.

Kerr RG, Kerr SS 1999. Marine natural products as therapeutic agents. Exp Opin Ther Patents 9: 1207-1222.
Kossuga MH, Lira SP, Nascimento AM, Gambardella MTP, Berlinck RGS, Torres YR, Nascimento GGF, Pimenta EF, Silva M, Thiemann OH, Oliva G, Tempone AG, Melhem MSC, Souza AO, Galetti FCS, Silva CL, Cavalcanti B, Pessoa CO, Moraes MO, Hajdu E, Peixinho S, Rocha RM 2007. Isolamento e atividades biológicas de produtos naturais das esponjas Monanchora arbuscula, Aplysina sp., Petromica ciocalyptoides e Topsentia ophiraphidites, da Ascídia Didemnum ligulum e do Octocoral Carijoa riisei. Quim Nova 30: 1194-1202.

Kossuga MH, MacMillan JB, Rogers EW, Molinski TF, Nascimento GGF, Rocha RM, Berlinck RGS 2004. (2S,3R)-2-Aminododecan-3-ol, a new antifungal agent from the ascidian Clavelina oblonga, J Nat Prod 67: 1879-1881.

Kubanek J, Whalen KE, Engel S, Kelly SR, Henkel TP, Fenical W, Pawlik JR 2002. Multiple defensive roles for triterpene glycosides from two Caribbean sponges. Oecologia 131: 125-136.

Kuniyoshi M, Higa $\mathrm{T}$ 2001. Recent developments on antimicrobial metabolites from marine sponges. In: Fingerman M, Nagabhushanam R (Eds.) Recent Advances in Marine Biotechnology. Enfield (NH), USA: Science Publishers, Inc., vol. 6, Bioorganic Compounds: Chemistry and Biomedical Applications, p. 21-84.

Lindel T, Hofmann H, Hochgürtel M, Pawlik JR 2000. Structure-activity relationship of inhibition of fish feeding by sponge-derived and synthetic pyrroleimidazole alkaloids. J Chem Ecol 26: 1477-1496.

Lindquist N 2002. Chemical defense of early stages of benthic marine invertebrates. J Chem Ecol 28: 1987-2000.

Lindquist N 1996. Palatability of invertebrate larvae to corals and sea anemones. Mar Biol 126: 745-755.

Lira TO, Nascimento GFF, Hajdu E, Berlinck RGS 2006. Further Dibromotyrosine-Derived Metabolites from the Marine Sponge Aplysina caissara. J Braz Chem Soc 17: 1233-1240.

Longley RE, McConnell OJ, Essich E, Harmody D 1993. Evaluation of marine sponge metabolites for cytotoxicity and signal-transduction activity. $J$ Nat Prod 56: 915-920.

Maia LF, Epifanio RD, Fenical W 2000. New cytotoxic sterol glycosides from the octocoral Carijoa (Telesto) riisei. J Nat Prod 63: 1427-1430.

Marin A, López MD, Esteban MA, Mesegner J, Muñoz J, Fontana A 1998. Anatomical and ultrastructural studies of chemical defense in the sponge Dysidea fragilis. Mar Biol 131: 639-645.

Martín D, Uriz MJ 1993. Chemical bioactivity of Mediterranean benthic organisms against embryos and larvae of marine invertebrates. J Exp Mar Biol Ecol 173: 1127.

Mayer AMS 1999. Marine pharmacology in 1998: antitumor and cytotoxic compounds. The Pharmacologist 41: 159-164.

Mayer AMS, Gustafson KR 2003. Marine pharmacology in 2000: antitumor and cytotoxic compounds. Int $J$ Canc 105: 291-299.

Mayer AMS, Lehmann VKB 2001. Marine pharmacology in 1999: antitumor and cytotoxic compounds. Anticanc Res 21: 2489-2500. 
Mayer AMS, Hamann MT 2002. Marine pharmacology in 1999: compounds with antibacterial, anticoagulant, antifungal, anthelmintic, anti-inflammatory, antiplatelet, antiprotozoal and antiviral activities affecting the cardiovascular, endocrine, immune and nervous systems, and other miscellaneous mechanisms of action. Comp Biochem Physiol 132C: 315-339.

Mayer AMS, Gustafson KR 2006. Marine pharmacology in 2003-4: Antitumor and cytotoxic compounds. Eur J Cancer 43: 2241-2270.

Mayer AMS, Rodriguez AD, Berlinck R, Hamann MT 2007. Compounds with anthelmintic, antibacterial, anticoagulant, antifungal, anti-inflammatory, antimalarial, antiplatelet, antiprotozoal, antituberculosis, and antiviral activities; affecting the cardiovascular, immune and nervous systems, and other miscellaneous mechanisms of action. Comp Biochem Physiol 145C: 553-581.

McClintock JB, Baker BL 1997. Palatability and chemical defense of eggs, embryos and larvae of shallowwater Antarctic marine invertebrates. Mar Ecol Prog Ser 154: 121-131.

Monks NR, Lerner C, Henriques AT, Farias FM, Schapoval EES, Suyenaga ES, da Rocha AB, Schwartzman G, Mothes B 2002. Anticancer, antichemotactic and antimicrobial activities of marine sponges collected off the coast of Santa Catarina, southern Brazil. $J$ Exp Mar Biol Ecol 281: 1-12.

Munro MHG, Blunt JW, Dumdei EJ, Hickford SJH, Lill RE, Li S, Battershill CN, Duckworth AR 1999. The discovery and development of marine compounds with therapeutic potential. J Biotechnol 70: 15-25.

Munro MHG, Blunt JW 2007. MARINLIT, a database of the marine natural products literature. Department of Chemistry, University of Canterbury, Christchurch, New Zealand, vpc 12.5 .

Muricy G, Hajdu E, Araújo FV, Hagler AN 1993. Antimicrobial activity of Southwestern Atlantic Shallow-Water marine sponges (Porifera). Sci Mar 57: 427-432.

Mutter R, Wills M 2000. Chemistry and clinical biology of the bryostatins. Bioorg Med Chem 8: 1841-1860.

Nakamura H, Kobayashi J, Ohizumi Y, Hirata Y 1982. Isolation and structure of aaptamine a novel heteroaromatic substance possessing a-blocking activity from the sea sponge Aaptos aaptos. Tetrahedron Lett 23 5555-5558.

Nakamura H, Kobayashi J, Ohizumi Y, Hirata Y 1987. Aaptamines. Novel benzo[de][1,6]naphthyridines from the Okinawan sponge Aaptos aaptos. J Chem Soc Perkin Trans I: 173-176.

Nascimento GGF, Locatelli J, Freitas PC, Silva GL 2000. Antibacterial activity of plant extracts and phytochemicals on antibacterial-resistant bacteria. Braz J Microbiol 31: 247-256.

Newman DJ, Cragg GM, Snader KM 2003. Natural products as sources of new drugs over the period 1981-2002. J Nat Prod 66: 1022-1037.

Nicholas GM, Eckman LL, Ray S, Hughes RO, Pfefferkorn JA, Barluenga S, Nicolaou KC, Bewley CA 2002. Bromotyrosine-derived natural and synthetic products as inhibitors of mycothiol-S-conjugate amidase. Bioorg Med Chem Lett 12: 2487-2490.
Nicholas GM, Eckman LL, Newton GL, Fahey RC, Ray S, Bewley CA 2003. Inhibition and kinetics of Mycobacterium tuberculosis and Mycobacterium smegmatis mycothiol-S-conjugate amidase by natural product inhibitors. Bioorg Med Chem 11: 601-608.

O'Neal W, Pawlik JR 2002. A reappraisal of the chemical and physical defenses of Caribbean gorgonian corals against predatory fishes. Mar Ecol Prog Ser 240: 117-126.

Oliveira JHHL, Grube A, Köck M, Berlinck RGS, Macedo ML, Ferreira AG, Hajdu E 2004. Ingenamine G and cyclostelletamines $\mathrm{G}$ - $\mathrm{K}$ from the new Brazilian species of marine sponge Pachychalina sp. $J$ Nat Prod 67: 1685-1689.

Oliveira MF, Oliveira JHHL, Galetti FCS, Souza AO, Silva CL, Hajdu E, Peixinho S, Berlinck RGS, 2006a. Antimycobacterial brominated metabolites from two species of marine sponges. Planta Med 72: 437-441.

Oliveira JHHL, Seleghim MHR, Timm C, Grube A, Köck M, Nascimento GGF, Martins ACT, Silva EGO, Souza AO, Galetti FCS, Minarini PRR, Silva CL, Hajdu E, Berlinck RGS 2006b. Antimicrobial and antimycobacterial activity of cyclostellettamine alkaloids from sponge Pachychalina sp. Mar Drugs 4: 1-8.

Oliveira JHHL, Nascimento AM, Kossuga MH, Cavalcanti BC, Pessoa C, Moraes MO, Macedo ML, Ferreira AG, Hajdu E, Pinheiro U, Berlinck RGS 2007. Cytotoxic alkylpiperidine alkaloids from the Brazilian marine sponge Pachychalina alcaloidifera. J Nat Prod 70: 538-543.

Patrick GL, 2001. An Introduction to Medicinal Chemistry. Oxford, Oxford University Press.

Paul VJ 1992. Chemical Defenses of Benthic Marine Invertebrates. In: Paul VJ (Ed.) Ecological Roles of Marine Natural Products. Ithaca, Cornell University Press, Comstock Publishing Associates, p. 164-188.

Pawlik JR 1992. Chemical ecology of the settlement of benthic marine invertebrates. Oceanog Mar Biol Ann Rev 30: 273-335.

Pawlik JR 1993. Marine invertebrate chemical defenses. Chem Rev 93: 1911-1922.

Pawlik JR, Chanas B, Toonen RJ, Fenical W 1995. Defenses of Caribbean sponges against predatory reef fish. I. Chemical deterrence. Mar Ecol Prog Ser 127: 183194.

Peng JN, Shen XY, EL Sayed, KA, Dunbar DC, Perry TL, Wilkins SP, Hamann MT 2003. Marine natural products as prototype agrochemical agents. J Agr Food Chem 51: 2246-2252.

Pettit GR 1991. The bryostatins. Progr Chem Org Nat Prod 57: 153-195.

Pisut DP, Pawlik JR 2002. Anti-predatory chemical defenses of ascidians: secondary metabolites or inorganic acids? J Exp Mar Biol Ecol 270: 203-214.

Prado M, Torres YR, Berlinck RGS, Desiderá C, Sanchez MA, Craveiro MV, Hajdu E, Rocha RM, Machado-Santelli GM 2004. Effects of marine organisms extracts on microtubule integrity and cell cycle progression in cultured cells. J Exp Mar Biol Ecol 313: 125-137.

Proksch P, Edrada RA, Ebel R 2002. Drugs from the seas current status and microbiological implications. Appl Microbiol Biotechnol 59: 125-134. 
Quinn RJ, Leone PA, Guymer G, Hooper JNA 2002. Australian biodiversity via its plants and marine organisms. A high-throughput screening approach to drug discovery. Pure Appl Chem 74: 519-526.

Rangel M, de Sanctis B, de Freitas JC, Polatto JM, Granato AC, Berlinck RGS, Hajdu E 2001. Cytotoxic and neurotoxic activities in extracts of marine sponges (Porifera) from southeastern Brazilian coast. $J$ Exp Mar Biol Ecol 262: 31-40.

Rao MR, Venkatesham U, Sridevi KV, Venkateswarlu Y 2000. Chemical constituents and their biological activities of the sponge family Aplysinellidae: A review. Ind $J$ Chem 39: 723-733.

Rinehart KL 2000. Antitumor compounds from tunicates. Med Res Rev 20: 1-27.

Roberge M, Berlinck RGS, Xu L, Anderson H, Lim LY, Curman D, Stringer CM, Friend SH, Davies P, Vincent I, Haggarty SJ, Kelly MT, Britton R, Piers E, Andersen RJ 1998. High throughtput assay for G2 checkpoint inhibitors and identification of the structurally novel compound isogranulatimide, Cancer Res 58: 57015706.

Rudi A, Kashman Y 1993. Aaptosine - a new cytotoxic 5,8diazabenz[cd]azulene alkaloid from the Red Sea sponge Aaptos aaptos. Tetrahedron Lett 34: 46834684.

Saeki BM, Granato AC, Berlinck RGS, Magalhães A, Schefer AB, Ferreira AG, Pinheiro UG, Hajdu E 2002. Two unprecedented dibromotyrosine-derived alkaloids from the Brazilian endemic marine sponge Aplysina caissara. J Nat Prod 65: 796-799.

Schmitz FJ 1994. Cytotoxic compounds from sponges and associated microfauna. In: van Soest RWM, Van Kempen TMG, Braekman JC (Eds.) Sponges in Time and Space. Rotterdam, The Netherlands: Balkema, p. 485-495.

Selvin J, Lipton AP 2004. Biopotentials of secondary metabolites isolated from marine sponges. Hydrobiologia 513: 231-238.

Sharma GM, Vig B 1972. Studies on antimicrobial substances of sponges. 6. Structures of 2 antibacterial substances isolated from the marine sponge Dysidea herbacea. Tetrahedron Lett 17: 1715-1718.

Shen YC, Lin TT, Sheu JH, Duh CY 1999. Structures and cytotoxicity relationship of isoaaptamine and aaptamine derivatives. $J$ Nat Prod 62: 1264-1267.

Sings HL, Rinehart KL 1996. Compounds produced from potential tunicate-blue-green algal symbiosis: a review. J Ind Microbiol Biotechnol 17: 385-396.

Skehan P, Storeng R, Scudiero D, Monks A, McMahon J, Vistica D, Warren JT, Bodesch H, Kenney S, Boyd MR 1990. New colorimetric cytotoxicity assay for anticancer - drug screening. J Natl Cancer Inst 82: 1107-1112.

Slattery M, Hamann MT, McClintock JB, Perry TL, Puglisi MP, Yoshida WY 1997. Ecological roles for waterborne metabolites from Antarctic soft corals. Mar Ecol Prog Ser 161: 133-144.

Stachowicz JJ, Lindquist N 1997. Chemical defense among hydroids on pelagic Sargassum: predator deterrence and absorption of solar UV radiation by secondary metabolites. Mar Ecol Prog Ser 155: 115-126.

Stachowicz JJ 2001. Chemical Ecology of Mobile Benthic Invertebrates: Predators and Prey, Allies and Competitors, In: McClintock JB, Baker BJ (Eds.) Marine Chemical Ecology. Boca raton, USA: CRC Press, p. 157-194.
Takamatsu S, Hodges TW, Rajbhandari I, Gerwick WH, Hamann MT, Nagle DG 2003. Marine natural products as novel antioxidant prototypes. J Nat Prod 66: 605-608.

Tinto WF 1998. Aaptosamine, a new 5,8-diazabenz[cd][azulene alkaloid from the Caribbean sponge Aaptos aaptos. An unprecedented base-catalyzed rearrangement of 9-demethyloxyaaptamine. Heterocycles 48: 20892093.

Torres YR, Berlinck RGS, Nascimento GGF, Fortier SC, Pessoa C, Moraes MO 2002a. Antibacterial activity against resistant bacteria and cytotoxicity of four alkaloid toxins isolated from the marine sponge Arenosclera brasiliensis. Toxicon 40: 885-891.

Torres YR, Bugni TS, Berlinck RGS, Ireland CM, Magalhães A, Ferreira AG, Rocha RM 2002b. Sebastianines $\mathrm{A}$ and $\mathrm{B}$, novel biologically active pyridoacridine alkaloids from the Brazilian Ascidian Cystodytes dellechiajei. J Org Chem 67: 5429-5432.

Turon X, Becerro MA, Uriz MJ 1996. Seasonal patterns of toxicity in benthic invertebrates: the encrusting sponge Crambe crambe (Poecilosclerida). Oikos 75: 33-40.

Turon X, Tarjuelo I, Uriz MJ 1998. Growth dynamics and mortality of the encrusting sponge Crambe crambe (Poecilosclerida) in contrasting habitats: correlation with population structure and investment in defense. Funct Ecol 12: 631-639.

Tuttle JV, Krenitsky TA 1980. Purine phosphoribosyl transferases from Leishmania donovani. J Biol Chem 255: 909-916.

Uriz MJ, Turon X, Becerro MA 1995. Patterns of resource allocation to somatic, defensive, and reproductive functions in the Mediterranean encrusting sponge Crambe crambe (Demospongiae, Poecilosclerida). Mar Ecol Prog Ser 124: 159-170.

Uriz MJ, Becerro MA, Tur JM, Turon X 1996. Location of toxicity within the Mediterranean sponge Crambe crambe (Demospongiae: Poecilosclerida). Mar Biol 124: 583-590.

Van Alstyne KL, Wylie CR, Paul VJ 1994. Antipredator defenses in tropical Pacific soft corals (Coelenterata: Alcyonacea). II. The relative importance of chemical and structural defenses in three species of Sinularia. J Exp Mar Biol Ecol 178: 17-34.

Van Soest RWM, Braekman JC, Faulkner DJ, Hajdu ECM, Harper MK, Vacelet J 1996. The genus Batzella: a chemosystematic problem. Bull Inst Royal Sci Nat Belg 66: 89-101.

Vervoort HC, Pawlik JR, Fenical W 1998. Chemical defense of the Caribbean ascidian Didemnum conchyliatum. Mar Ecol Prog Ser 164: 221-228.

Vervoort H, Fenical W, Epifanio RA 2000. Tamandarins A and B: New cytotoxic depsipeptides from a Brazilian ascidian of the family Didemnidae. J Org Chem 65: 782-792

Waddell B, Pawlik JR 2000. Defenses of Caribbean sponges against invertebrate predators. I. Assays with hermit crabs. Mar Ecol Prog Ser 195: 125-132.

Wahl M, Jensen PR, Fenical W 1994. Chemical control of bacterial epibiosis on ascidians. Mar Ecol Prog Ser 110: 45-57.

Watters DJ, van den Brenk AL 1993. Toxins from ascidians. Toxicon 31: 1349-1372.

Xue S, Zhang HT, Wu PC, Zhang W, Yuan Q 2004. Study on bioactivity of extracts from marine sponges in Chinese Sea. J Exp Mar Biol Ecol 298: 71-78. 